\title{
Türk runik metinleri ile Nogay Türkçesinin ortak söz varlı̆̆ı
}

\section{Süleyman Hilmi KIZILDAĞ'}

APA: Kızıldağ, S. H. (2020). Türk runik metinleri ile Nogay Türkçesinin ortak söz varlığı. RumeliDE Dil ve Edebiyat Araştırmaları Dergisi, (Ö7), 111-151. DOI: 10.2900o/rumelide.808267.

\section{$\ddot{\mathbf{O} z}$}

Türklere ait ilk yazılı belgeler, Eski Türkçe döneminde, Türk runik alfabesiyle çoğunluğu yazıt taşlara olmak üzere kayalara, sert cisimlere, çeşitli eşyalara ve kâğıtlara yazılmıştır. Günümüze kadar Eski Türk runik metinlerinin üzerine Türkologlar birçok farklı konuda çalışmalar yapmıştır. Bu konulardan biri de söz varlığı çalışmalarıdır. Zaman zaman Türk runik metinlerinin söz varlığı çağdaş Türk lehçeleri söz varlığıyla karşılaştırılmıştır. Çünkü Türk lehçeleri çalışmalarında temel dayanak olarak Eski Türkçenin araştırılmasının ve lehçeler ile ilişkisinin ortaya çıkarılmasının önemi büyüktür. Tarafımızca yapılan araştırmada temel konu olarak Türk runik metinleri söz varlığı ile Nogay Türkçesi söz varlığının karşılaştırıldığı bir çalışma tespit edilememiştir. Bu çalışmada, Türk runik metinlerinde var olan sözcükler ile çağdaş Nogay Türkçesi sözlüklerinde yaşamaya devam eden ortak sözcüklerin tespit edilmesi amaçlanmıştır. Çalışmada öncelikle eski Türk yazıtları söz varlığının çağdaş Türk lehçeleri söz varlığı ile karşılaştırıldığı çalışmalar belirtilmiştir. Daha sonra Nogay Türkçesinde yaşamaya devam eden Eski Türkçe sözcükler tespit edilmiştir. Bu sözcükler, "fonetik değişikliğe uğramış ve/veya morfolojik olarak farklı olan” ve "fonetik ve morfolojik olarak değişmeyen” sözcükler olmak üzere sınıflandırılmıştır. Sözcüklerin ortak olma durumunda bazı sözcüklere temkinli yaklaşılarak dipnotlarda, sözcüğün etimolojisiyle ilgili değerlendirmelere yer verilmiştir. Ayrıca morfolojik olarak farklı biçimde oluşmuş sözcükler üzerine açıklamalar yapılmıştır. Çalışmanın sonuç bölümünde ortak sözcükler üzerine istatistikî bilgiler, sözcüklerde gerçekleşen ses olayları ve semantik olarak değişmeler tespit edilmiştir.

Anahtar kelimeler: Türk runik metinleri, Nogay Türkçesi, söz varlığı

\section{Common vocabulary of Turkish runic texts and Nogay Turkish}

\begin{abstract}
In the period of Old Turkic Language, the first written documents belonging to the Turks were written in rocks, hard objects, various objects and papers, mostly in the inscription stones, in the Turkish Runic alphabet. Until today, Turkologists have worked on many different subjects on Old Turkish runic texts. One of these issues is vocabulary studies. From time to time the vocabulary of runic texts has also been compared to the vocabulary of contemporary Turkish dialects. This is because it has a significant importance to investigate the old Turkish as the main basis in the study of Turkish dialects and to reveal its relationship with the dialects. In the inquiries that we made, a study comparing vocabularies of Turkish runic texts and Nogay Turkish as the main subject was not determined. In this study, it is aimed to identify the words existing in Turkish runic texts and the common words that continue to live in contemporary Nogay Turkish dictionaries. In the study, firstly, studies comparing the old Turkish inscriptions vocabulary with the modern Turkish dialects
\end{abstract}

1 Doktora öğrencisi, İnönü Üniversitesi, Sosyal Bilimler Enstitüsü, Türk Dili ve Edebiyatı ABD (Malatya, Türkiye), shkizildag@gmail.com, ORCID ID: 00oo-0003-4107-923X [Makale kaylt tarihi: 24.06.2020-kabul tarihi: 20.10.2020; DOI: $10.29000 /$ rumelide.808267] 
vocabulary are specified. After that, Old Turkish words that continue to live in Nogay Turkish were determined. These words are classified as "phonetically modified and/or morphologically different" and "phonetically and morphologically unchanged" words. In the case of common words, some words are cautiously approached and evaluations about the etymology of the words are included in the footnotes. In addition, explanations were made on words that were formed morphologically different. In the conclusion part of the study, statistical information on common words, sound events in words and semantic changes were determined.

Keywords: Turkish runic texts, Nogay Turkish, vocabulary

\section{Giriş}

Tarih boyunca Türkler, coğrafi açıdan çok hareketlilik gösteren bir millet olmuşlardır. Bu da Türkçenin, dünyada en geniş alana yayılan ve konuşulan diller arasında yer almasını sağlamıştır. Yaşanılan farklı coğrafyalar zamanla farklı lehçelerin oluşmasına zemin hazırlamıştır. Türk dilinin lehçelere ayrılmasını bir ağaç gövdesinin dallara ayrılması şeklinde düşündüğümüzde konunun temeline, bilinen en eski Türk dili kaynakları olması nedeniyle, Türk runik harfli metinleri ve bu metinlerdeki dil özelliklerini koymalıyız. Dolayısıyla Türk lehçeleri araştırmalarında temel dayanak olarak Eski Türkçe araştırmalarının önemi büyüktür.

Türk runik metinlerinin bulunmalarından bu yana bu metinler üzerine okuma ve anlamlandırma çalışmaları sürekli yapılmaktadır. Eski Türkçe metin anlamlandırmalarında karşılaştırmalı lehçe çalışmaları Türkologlara yardımcı olacaktır. Bu çalışmaların, hem lehçelere temel dayanak olması yönüyle lehçe araştırmalarına hem de Eski Türkçede kullanılan sözcüklerin, bazı ses değişiklikleriyle de olsa, lehçelerde hâlâ kullanılması Eski Türkçe araştırmalarına yararlı olacaktır.

Bu çalışmada, Türk runik harfli metinlerin söz varlığı ile çağdaş Kıpçak Türk lehçelerinden Nogay Türkçesinin söz varlığ karşılaştırılmış ve Nogay Türkçesinde yaşayan ortak kelimeler belirlenmiştir. Karşlaştırma yapmadan önce Türk runik harfli metinlerin büyük çoğunluğu incelenmiştir. Runik metinlerin söz varlığı tespit edilirken T. Tekin'in Orhon Türkçesi Grameri (2003), H. N. Orkun'un Eski Türk Yazıtları (2011), L.N. Tıbıkova-İ.A. Nevskaya-M. Erdal'nn Katalog Drevnetyurkskih Runiçeskih Pamyatnikov (2012)2, R. Alimov'un Tanrı Dağı Yazıtları (2014)3, C. Alyılmaz’ın İpek Yolu Kavşağının Ölümsüzlük Eserleri (2015), E. Aydın'ın Yenisey Yazıtları (2015)4, Orhon Yazıtları (2017), Uygur Yazıtları (2018), H. Şirin'in Eski Türk Yazıtları Söz Varlı̆̆ İncelemesi (2016) ve F. Yıldırım'ın Irk Bitig ve Orhon Yazılı Metinlerin Dili (2017) 5 adlı eserleri esas alınmıştır. Bu eserlerde bulunmayan bazı runik metinler için de çeşitli makaleler ve eserlerden yararlanılmıştır. Bunlar, çalışmanın kaynakça bölümünde belirtilmiştir. Nogay Türkçesi için ise N.A. Baskakov'un Nogaysko-Russkiy Slovar (1963) adlı eseri esas alınmıştır. Bu sözlükte bulunmayan sözcükler yine N.A. Baskakov'un Russko-Nogayskiy Slovar (1956) adlı eserinde ve S. A. Canibekova-Qalmıqova, M.A.Bulgarova, S.A.Quqayeva'nın Nogaysko-Russkiy Slovar (2018) adlı eserinde aranmıştır.

Türk runik metinlerinde özel isimleri (kişi, yer, millet, boy, dağ, ırmak, göl vs.), oluşturulma sistemi farklı olduğundan birleşik sayıları ve aynı eylemlerin hem olumlu hem de olumsuz şekilleri varsa olumsuz şekilleri karşılaştırma için kullanılmadığında karşımıza 1264 farklı sözcük çıkmıştır.

Çalışmamızda Dağlık Altay Yazıtları için bu eserdeki numaralandırma esas alınmıştır. Çalışmamızda Tanrı Dağı Yazıtları için bu eserdeki numaralandırma esas alınmıştır.

Çalışmamızda Yenisey Yazıtları için bu eserdeki numaralandırma esas alınmıştır.

Çalışmamızda Irk Bitig ve kağıda yazılı runik metinler için bu eserdeki numaralandırma esas alınmıştır. 
Çalışmada, runik metinlerdeki sözcüklerin yanına parantez içinde sözcüğün hangi yazıtlarda/ metinlerde tanıklandığı ve satır numarası belirtilmiştir. Makalenin hacmi sınırlı olduğu için bir sözcüğün geçtiği bütün runik metinleri belirtmek yerine en fazla beş yer belirtilmiştir. Runik metinde bazı sözcüklerin türemiş biçimi bulunup kök biçimi bulunmadığında, aynı sözcüğün Nogay Türkçesi sözlüğünde de türemiş biçimi bulunmayıp kök biçiminin bulunduğu veya tam tersi durumlarda sözcükler olduğu gibi karşlaş̧ırılmıştır. Sözcüklerin kökleri aynı olup farklı eklerle türetildiği durumlarda da sözcükler olduğu gibi karşılaştırılmıştır. Bu durumdaki sözcükler dipnotlarda belirtilmiştir. Dipnotlarda ayrıca gerekli görülen sözcükler üzerine morfolojik, etimolojik ve semantik açıklamalar yapılmıştır. Farklı sözcüklerdeki aynı eklerle ilgili morfolojik açıklamalar, tekrara düşmemek için her sözcükte yapılmamıştır.

\section{Eski Türk yazıtları söz varlığının çağdaş Türk lehçeleri söz varlığı ile karşılaştırıldığı çalışmalar}

Aşağıda sıralandığı üzere eski Türk yazıtlarının söz varlığı birçok çağdaş Türk lehçesinin söz varlığı ile karşılaştırılmıştır. Temel konu olarak Nogay Türkçesi ile karşlaştırılan bir makale tespit edilememiştir. Aşağıda sıralanan makalelerden D. Ergönenç Akbaba'nın "Nogay Türkçesi ve Türkiye Türkçesi Arasındaki Yalancı Eş Değerler” adlı makalesinde Nogay Türkçesi ile Türkiye Türkçesi arasında 80 adet yalancı eş değer sözcük tespit edilmiş ve bu Nogay Türkçesindeki 80 adet sözcüğün Eski Türkçedeki biçimleri belirtilmiştir.

Adılov, M. (2018). Kazakça Atasözü ve Deyimlerde Eskicil Unsurlar. Doktara Tezi. İzmir: Ege Üniversitesi.

Adzhimambetova, G. (2011). Orhun-Yenisey Anıtlarında Rastkelgen Zarflarnıng Modern Kırım Tatar Dilinde İşletilüvi. III. Uluslararası Dünya Dili Türkçe Sempozyumu Bildiri Kitabı, 27-30.

Ahmetov, M. A. (1978). Glagol v Yazıke Orhono-Yeniseyskih Pamyatnikov: v sravnitel'nom plane s sovremennım Başkirskim yazıkom. Saratov: İzdatel'stvo Saratovskogo Universiteta.

Akan Budak, D. (2012). Erzurum Ağzı Söz Varlığında Eski Türkçenin İzleri. TSt, 7/4, 629-646.

Akar, A. (2005). Kazak Türkçesinde Köktürkçe Sözlüksel Unsurlar. Türk Dünyası Dil ve Edebiyat Dergisi, 20, 21-26.

Akilova, M. F. (2015/1). Nekotarıye Sledı Yazıka Orhono-Yeniseyskih Pamyatnikov v Sovremennom Başkirskom i Drugih Tyurkskih Yazıkah, na Materiale Nazvaniy, Otnosyatsihsya k Pripode. Sovremennye Problemi Nauki i Obrazovaniya.

Asımkhan, J. (2016). Köktürk Harfli Yazıtlar ile Kazak Türkçesinin Ağızlarında Bulunan Ortak Kelimeler. I. Uluslararası Öğrenciler Sosyal Bilimler Kongresi, 31-36.

Ata, A. (2000). Derleme Sözlüğü'nde Geçen En Eski Türkçe Kelimeler I. Türkoloji Dergisi, 15/1, 67-97.

Ayazlı, Ö. (2016). Eski Uygurca Din Dışı Metinlerin Karşılaştırmalı Söz Varlığı. Ankara: Türk Dil Kurumu Yayınları.

Balci, O. (2015). Türkiye Türkçesi ve Kazak Türkçesi Örnekleriyle Orhun Yazıtları'nın Çağdaş Türk Lehçelerine Aktarma Farklılıkları. Türk Dünyası, 40, 7-20.

Baran, B. (2008). Eski Türkçeden Anadolu Ağızlarına Ulaşan Bazı Kelimeler. TDİD, 8/1, 41-47.

Begmatov, E. (2003). Old Turkic Name Elements in Modern Uzbek Anthroponymy. IJCAS, 8, 240260.

Cin, A. \& Tokay, Y. (2012). Bengü Taşların Söz Varlığı ile Türkiye Türkçesi Ağızlarının Söz Varlığının Karşılaştırılması. TSt, 7/1, 653-703. 
Çelikel, S. (2007). Orhun Kitabelerinin Günümüz Türkçesindeki Söz Varhğg. Yüksek Lisans Tezi. Edirne: Trakya Üniversitesi.

Doerfer, G. (1974). Eski Türkçe ile Halaçça Arasında Şaşırtıcı Bir Koşutluk. (çev. Semih Tezcan). TDAY-Belleten, 13-24.

Ercilasun, A. B. (1996). Köktürkçe ile Tatar Türkçesi Arasındaki Benzerlikler. Türk Kültürü Araştırmaları (Prof. Dr. Zeynep Korkmaz Armağanı). XXXII/1-2, 143-149.

Ergönenç Akbaba, D. (2007). Nogay Türkçesi ve Türkiye Türkçesi Arasındaki Yalancı Eş Değerler. Bilig, 42, 151-176.

Ersoy, F. (2015). Köktürk Harfli Yazıtlarla Çuvaşça Arasındaki Ortak Kelimeler. Dil Araştırmaları, Bahar, 51-82.

Figen Güner, D. (1997). Göktürk Bengü Taşlarından Günümüz Altay Türkçesine Ulaşan Kelimeler. Sibirya Araştırmaları, 139-145.

Gülsevin, G. (1990). Göktürk Anıtları İle Yaşayan Üç Lehçemizin (Halaç, Çuvaş ve Saha/Yakut) Tarihi İlgi Düzeni. TDAY-Belleten, 55-64.

Harmanda, S. (2008). Günümüz Türkmen Türkçesinin Kelime Hazinesi ile Eski Türkçenin Kelime Hazinesinin Karşılaştırılması. Yüksek Lisans Tezi. Ankara: Gazi Üniversitesi.

Hisamova, F. M. (2015). Participle Forms in Orkhon-Yenisei Text and in the Tatar Language. Turkic Runiform, 201-205.

Kaljanova, E. (2013). Eski Türk Yazıtları ve Kazakçadaki Ortak Kelimeler. TDAY-Belleten, 223-244.

Karagöz, E. (2011). Günümüz Başkurt ve Kazan Tatar Türkçelerindeki Ses Değişikliklerinin Eski Türkçe ve Günümüz Türkiye Türkçesiyle Karşılaştırılması. Dialektologiya, İstoriya $i$ Grammatiçeskaya, Stuktura Tyurkskih Yazlkov, Kazan, 232-238.

Karahan, L. (1993). Köktürk Kitabelerinden Günümüze Ulaşan Kelimeler. Türk Yurdu 422, 5-7.

Kayra, O. K. \& Bolatova, Ş. (1997). Çağdaş Kazak Türkçesiyle Göktürk Yazıtlarındaki Kelime ve Deyimler Arasındaki Benzerlikler. TDAY-Belleten, 43, 179-191. Aynı Yazı: (1998) TDA, 112, 209220.

Meng Y. (2006). Eerhun Yenisai Beiming Yu Hasake Yuyan Wenxue. YSXX, 2, 31-34.

Mirkamal, A. (2016). On Some Old Turkic Words In Kazakh. TDAY-Belleten, 59/1,51-59.

Ölmez, M. (2000). Tuvacanın Eskiliği Üzerine. TDA, 10, 133-138.

Ölmez, M. (2007). Tuwinischer Wortschatz mit alttürkischen und mongolischen Parallelen Tuvacanın Sözvarlı̆̆ Eski Türkçe ve Moğolca Denkleriyle. Wiesbaden.

Ölmez, M. (2007). Kırgızca ve Eski Türkçe Arasında Sözlüksel Karşılaştırmalar: 1. Ünlüler. II. Uluslararası Büyük Türk Dili Kurultayı (İhsan Doğramacı'ya Armağan), 423-430.

Ölmez, M. (2013). Eski Türkçe ile Tuvaca Arasındaki Paralellikler. Tyurkskaya Runika, 1, 21-25.

Öner, M. (2007). Karay Türkçesinde Eski Unsurlar. IV Uluslararası Türk Dili, II, 1291-1296.

Özek F. \& Aytaç, A. (2011). Orhun Yazıtlarındaki Söz Varlığının Türkiye Türkçesi Ağızlarındaki İzleri. 38. ICANAS, 3, 1307-1317.

Şirin User, H. (2008). Eski Türkçeden Başkurtçaya Kent, Konut, Yerleşim, Nomenclaturası Üzerine Notlar. Tarihten Bugüne Başkurtlar, Dil-Tarih ve Kültür Üzerine İncelemeler, Ankara: Ötüken Yayınları. 294-312.

Tarlacı, O. (2018). Kö/ül Tẻgin Yazıtında Geçen Eylemlerin Tıva Türkçesinde Durumu. Uluslararası Beşeri Bilimler ve Eğitim Dergisi (IJHE), 5/10, 57-76.

Toprak, F. (2011). Orhon Yazıtlarından Anadolu Ağızlarına Karşılaştırmalı Dil Çalışmaları ve İki Örnek Eylem. III. Uluslararası Türkiyat, 2, 831-835. 
Yıldırım, T. \& Koca, D. (2014). Kazak Türkçesinde Geçen Eski Türkçe Kelimeler. Türk Dünyası, 37, 97109.

Yıldız, H. (2006). Yakutça ve Eski Türkçenin Söz Varlığı Üzerine Bir Karşılaştırma. Sibirya Incelemeleri, 1/2, 177-221.

Yıldız, H. (2007). Orhon Türkçesi ile Yakutçanın Söz Varlı̆̆ ve Söz Yapımı Bakımından Karşılaştırılması. Yüksek Lisans Tezi. Eskişehir: Anadolu Üniversitesi.

Yıldız, H. (2007). Orhon Yazıtlarından Yakutça ve Dolgoncaya Ulaşan Eskicil Sözvarlığı. Sibirya Incelemeleri, 2/1, 13-40.

Yıldız, H. (2015). Eski Türkçe ile Yakutçanın Sözvarlığının Ünlüyle Başlayan Sözcükler Bakımından Karşılaştırılması. Doktora Tezi. İstanbul: Yıldız Teknik Üniversitesi.

Yılmaz, M. (2011). Orhun Yazıtlarının Söz Varlığı ile Çuvaşçanın Söz Varlığının Fonetik Açısından Karşılaştırılması. TDA, 191, 65-83.

\section{Fonetik değişikliğe uğramış ve/veya morfolojik olarak farklı olan sözcükler}

\section{1. Ad soylu sözcükler}

1. aç: aç, tok değil (BK D 38; T-13/6, T-13/6). Nog. aş: aç (NRS, 1963: 54).

2. açı: acı; “ne acı!” (E 48/2, E 48/8, E 98/2). Nog. aşı: acı (NRS, 1963: 55).

3. açuk: apaçık, belirgin (Ar 3; E 27/1, E 27/1). Nog. aşık: açık (NRS, 1963: 55).

4. adak: ayak (KT K 7, BK D 30). Nog. ayak: ayak (NRS, 1963: 56).

5. adaklıg: ayaklı (E 10/11, E 10/11, E 11/3, E 42/6). Nog. ayaklı: ayaklı (RNS, 1956: 358).

6. adaş: yoldaş, arkadaş, eş, dost (E 11/8, E 26/10; A 7/1). Nog. adas: adaş (NRS, 1963: 26).

7. adgır: aygir (KT D 35, 36, BK K 11; A 80/1; IrkB 56). Nog. aygur: aygir (NRS, 1963: 29).

8. adrg: ayı (E 68/18, E 68/18; AÖ-1; IrkB 6). Nog. ayvv: ayı (NRS, 1963: 32).

9. agıl: ağıl (Su 5; E 41/9; IrkB 47). Nog. avıl: köy (NRS, 1963: 23).

10. agır: önemli, ağır. (BK D 2, BK G 15, İA-ö 3; A 3/1). Nog. avır: ağır; zor (NRS, 1963: 23).

11. agız: ağız (IrkB 27, 65). Nog. avız: ağız (NRS, 1963: 23).

12 agulug: zehirli (T II T 14: A 28). Nog. uvls: zehirli (NRS, 1963: 378).

13 akça: akçe, para (E 78). Nog. akşa: para (NRS, 1963: 34). altınç: altıncı (HT VII/1, HT XII/2, KÇor 16). Nog. altınşı: altıncı (NRS, 1963: 39). altmış: altmış (Ta B 6, DU I 2; E 1/1, E 26/10, E 41/9). Nog. alpıs: altmış (NRS, 1963: 39).

16. altun: altın (KT G 5, KT K 12, BK K 3, T 48 vd.). Nog. altın: altın (NRS, 1963: 39). 

dillerinde "ata; büyükbaba; büyükanne; baba; anne; amca; hala; ağabey; abla; ebe" gibi anlamları karşıladığını belirtir (ED: 5).

8 Clauson, IrkB 6o’taki arah sözcüğü hakkında sözcügün ortasındaki ünlünün bilinmediğini, metinde geçen tokuz arah sıgun kiyik ifadesinden "dokuz aylık geyik" veya "boynuzu dokuz çatallı, aralı geyik" gibi anlamlar beklenebilirse de sözcügüün bu şeklinden o anlamların çıkarılamadığını belirtir. Ayrıca Clauson'a göre 8. yüzyıl Türk metinlerinde - $h$ ekinin bulunması mümkün değildir. Bu sözcük yabancı bir sözcügün bozulmuş hali olabilir (ED: 230). Gabain, Eski Türkçede sıralamalı cümle unsurlarının, bağlayıcı bir unsur olmadan, yan yana geldiğini ve birleşik kelimelere $+l I$ eki getirilerek yapıldığını belirtir (1988: 107). Tekin, Eski Türkçede aynı yapı ve görevde iki sözcüğün $+l I$ eki ile birleștirildiğini ve bu yapının yaygın olmadığını belirtir (2003: 104). Erdal, Eski Türkçenin Grameri’nde +lI ekini 'nominal inflexional' bölümünün alt başlığı olan 'antonymy and parallelism' başlığı altında inceler ve + $l I$ eki almış ilişkili isimlerin genellikle çift kelimelerle kullanıldığını belirtir (2004: 166). Uçar, "Eski Türkçe +lı eki üzerine" başlıklı makalesinde Eski Türkçe $+h$ ekinin 'syntactic' bir issleve sahip, cümle unsurlarının birbirleriyle ilisskisini sağlayan (agreement), çekimli olarak kullanılan bir hal eki olduğu için yapım eki olarak değerlendirilmesinin doğru olamadığını belirtir. Ayrıca + $h$ ekinin Eski Türkçede birliktelik ve bağlama hali olmak üzere iki işlevi de yüklendiğinin unutulmaması gerektiğini belirtir (2012: 135-142). Tekin, IrkB 6o’taki arlı/arah sözcügünün yapısının açılanmasının kolay olmadığını, hiç değilse de metnin anlam bütünlüğüne göre sözcüğün ara "iki nokta arasındaki mesafe" sözcüğü ile köktes olduğunu belirtir (2019: 46). Metnin yazıcısı arll/aral sözcüğünün sonunda yazım hatasıyla bir /g/ harfini yazmayı eğer unutmamışsa sözcükteki + ll eki ile Nogay Türkçesinde bulunan aralı sözcüğ̈̈ndeki $+l l$ (ET’deki +lıg ekinin devamı) eki farklı ekler olarak görünmektedir. Ancak sözcükler semantik açıdan uyuşmaktadır.

9 Clauson, asra sözcüğünün ast sözcüğünden kısaltılmıs zarf olduğunu belirtir (ED: 250); ast sözcüğünü "bir șeyin altı ya da alt yüzeyi” şeklinde açıklar ve aynı maddede asra sözcüğünün daha eski olduğunu belirtir (ED: 242). Gülensoy, ast sözcügüüün kökünün $a s$ olduğunu belirtir ve as sözcüğüne "aşağı, alt” anlamını verir (2007: 81). 
barduk13: bir savaş aleti (Or. 8212/76: (B) A 10). Nog. baldak: kılıç/hançer kolu, siperi (NRS, 1963: 69).

48. başlıg: lider; lideri olan (KT D 2, 15, BK D 3, vd.). Nog. baslı: başlı; akıllı (NRS, 1963: 73). bulunan azganakay sözcüğ̈̈ne bir başka küçültme eki olan -kAy eki getirilerek küçültme anlamı pekiştirilmiş görünmektedir.

11 Tezcan, sözcüğün Oğuz grubu Türk dillerinde baga; diğer Türk dillerinde baka biçiminde yaşadığını belirtir (1978: 68). ET baga sözcügüü üzerine Türkologların farklı görüşleri vardır. Bazı Türkologlar sözcüğü "kurbağa” anlamıyla ses yansımalı sözcük olarak $b \bar{a} k$ "croak" kökünden geliştiğini kabul ederler ve zamanla sözcüğe "kablumbağa" anlamının da verildiğini belirtirler. Bazı Türkologlar ise sözcüğü Sogdça vg "Tanrı" ile ilişkilendirirler (Aydın, 2018b: 103).

12 E 26/11'de bagır sözcüğ̈̈ “ah!, vah!” anlamında bir acınma ünlemi olarak bir durum karşısında yaşanan acıyı dile getirmiştir (Yıldırım, 2019: 275).

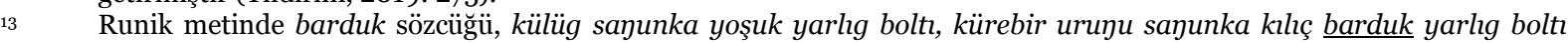
"Külüg Sayun'a miğfer tahsis edildi, Kürebir Sayun'a kılıç, barduk tahsis edildi” ibaresinin içinde geçmektedir. Yıldırım, barduk sözcügünü Divanü Lûgati’t-Türk’te geçen batrak "ucuna bir ipek parçası takılan mızrak” sözcügüüyle ilişkilendirir ve sözcüğe süpheli olarak "mızrak" anlamını verir (2017: 273-274). Söz konusu barduk sözcüğü şayet NTS'de ve diğer ÇKTL sözlüklerinde bulunan baldak sözcüğü ile ilişkili ise sözcükte bir sonraki yarlı sözcüğünde bulunan " $r$ " sesinin etkisiyle gerileyici uzak benzeşme olayı gerçekleşmiştir denilebilir. Bu durumda sözcüğe "mızrak" değil de "kılıçla ilgili bir nesne, kılıç kabzasının siperi” anlamı verilmelidir. Metinde barduk sözcüğünden önce kalıç sözcüğünün bulunması da bu düşüncemizi desteklemektedir.

14 bezek "süs, nakış" sözcüğü < bediz+e-k biçiminden gelişmiştir (Gülensoy, 2007: 137). 
51. bedük: büyük (O 6; E 45/10; IrkB 60). Nog. biyik: yüksek, yüce (NRS, 1963: 80).

52. beg: bey (KT D 20, BK D 16, O 9, KT G-B, vd.). Nog. biy: bey (NRS, 1963: 79).

53. belgü: işaret (Ta B 2, ŞU D 8,9, Tes G 3; T II T14:A14). Nog. belgi: işaret (NRS, 1963: 76).

54. belgülüg: açı, belirli; önemli (T II T 14: A 4). Nog. belgili: belli, işaretli (NRS, 1963: 76).

55. ben/men: birinci tekil kişi zamiri (T 1, 5, 7, BK K 9, vd.). Nog. men: ben (NRS, 1963: 221).

56. beylig: benli, (beyaz) lekesi olan (T 44). Nog. meyli: benli (yüz) (NRS, 1963: 221).

57. berü: beri, geri (T 46; E 73/7). Nog. beri: beri, bu tarafa (NRS, 1963: 77).

58. be்: kisrak (IrkB 5). Nog. biye: kısrak (NRS, 2018: 148).

59. bèl: bel, surt. (E 10/5, E 3/2). Nog. bel: bel; arka (NRS, 1963: 76).

6o. bẻş: beş (KT D 18, 31, KT K 4, BK D 15, 25, vd.). Nog. bes: beş (NRS, 1963: 78).

61. besşinç: beşinci (KT K 7, BK G 10; Ta G 2, vd.). Nog. besinşi: beşinci (NRS, 1963: 78).

62. bıy/biy/bin/mig: bin (T 14, 16, BK G 1, IrkB 32, vd.). Nog. mig: bin (NRS, 1963: 230).

63. bilig: bilgi, düşünce (T 6, KT G 5, 7, vd.). Nog. bilim¹5: bilgi, bilim (NRS, 1963: 80).

64. biligsiz: bilgisiz, cahil (KT D 5, 5, BK D 6, 6). Nog. bilimsiz: bilgisiz (NRS, 1963: 80).

65. biri: biri, bir kimse (U 5: (B1.II) A 3-4). Nog. birev: bir, biri (NRS, 1963: 82).

66. birki: birleşik (KT G 1, KT D 27, BK K 1, BK D 22). Nog. birge: beraber (NRS, 1963: 81).

67. birle: ile, birlikte (KT D 17, 26, 27, vd.). Nog. minen ${ }^{16}$ : ile, birlikte (Ergönenç, 2009: 210).

68. bo: bu (KT G 1, 2, 4, 10, 13, vd.). Nog. bu: bu (NRS, 1963: 87).

69. bod17: boy, halk (T 4, 60). Nog. boy: boy (NRS, 1963: 83).

70. boguz: bogaz (T 8). Nog. bogaz: boğaz (NRS, 1963: 83).

71. boş: boş, serbest; fazla (IrkB 29). Nog. bos: boş, serbest (NRS, 1963: 85).

72. boto: deve yavrusu (E 28/6). Nog. bota: deve yavrusu (NRS, 1963: 85).

ET bilig sözcüğü ile NT’deki bilim sözcüğünün kökü aynı ancak farklı eylemden ad türeten eklerle türetilmişlerdir. Clauson, ET birle sözcüğünün bir+la biçiminde oluștuğunu belirtir, sözcükteki $/ r /$ sesinin zamanla aşınmasıyla sözcügüun modern dillerde bile, bilen, vile, vilen, birlen, mınan, men, menen, ben, pen, bilan gibi çok çeşitli biçimlerinin ortaya çıtığını belirtir (ED: 364). Ergönenç NT minen edatının ET bilen, birle sözcügüunün değişmiş biçimi olduğunu belirtir (2009: 210).

17 Clauson, ET bod sözcügünün asıl anlamının "boy, insan boyu” olduğunu ancak en eski dönemlerden beri sözcüğün "klan, kabile, soy, nesil” anlamlarıyla da kullanıldığını belirtir (ED: 296-297). 
80 .

81.

82.

83.

84.

85.

86.

87.

88.

89.

90.

91.

92.

93.

94.

bugu: erkek geyik (E 98/6). Nog. bugı: erkek geyik (NRS, 1963: 88).

buka: boğa (T 5, 5, 6, 6; Kum). Nog. buga: boğa, öküz (NRS, 1963: 88).

bulganç: karışlk (T 22). Nog. bılganşık: karışık; çamurlu (NRS, 1963: 93).

bunça: bunca (KT G 2, 4, KT D 4, 10, 14, vd.). Nog. munşa: bunca (NRS, 1963: 227).

bunt: bunu (Ta K 5, 5, Ta Kaplumbağa). Nog. munt: işte bu (NRS, 1963: 227).

bunta: burada (KT G 10, 11, BK K 8, 8, vd.). Nog. munda: burada (NRS, 1963: 227).

buy: slkintı. (KT G 3, 8, BK K 2, T 57, vd.). Nog. muy: üzüntü, sıkıntı (NRS, 1963: 227).

buysuz: sıkıntısız (BK K 4, 12, 14, T 48, vd.). Nog. muysız: üzüntüsüz (NRS, 1963: 228).

butlug: bacaklı (E 46/3). Nog. but ${ }^{18}$ : kalça, but (NRS, 1963: 91).

buyruk: komutan (KT G 1, BK G 1, 14, vd.). Nog. buyrık: emir, ferman (NRS, 1963: 89).

buzagu: buzağı (IrkB 41). Nog. buzav: buzağı (NRS, 1963: 89).

çak: çağ, dönem (ŞU K 4). Nog. şak: çă̆, devir (NRS, 1963: 402).

çölgi: bozkırlı; sahra (T 23). Nog. şöl199: çöl (NRS, 1963: 416).

ederlig: eyerli (BO; A 80/3, A 80/3, A 80/3). Nog. iyer ${ }^{20}$ : at eyeri (NRS, 2018: 223).

egin: omuz, sırt; çatı (E 10/5; IrkB 18). Nog. iyin: omuz (NRS, 1963: 117).

elig $^{21}$ : elli (sayı) (KT D 8, BK D 7, BK G 7, T 42, vd.). Nog. elli: elli (NRS, 1963: 434).

emgek: slkıntı (KT D 19, BK D 16; IrkB 57). Nog. embek: yük, külfet (NRS, 1963: 434).

emig: meme (IrkB 24). Nog. emşek $^{22}$ : meme (NRS, 1963: 435).

ey I: en; daha (KT D 32, KT K 4, BK D 30, ŞU K 9, vd.). Nog. en: en (NRS, 1963: 436).

ey II: av; av hayvanı (IrkB 31, 31). Nog. ay: av; av hayvanı; canavar (NRS, 1963: 43).

erklig: güçlü, muktedir (BK K 12; IrkB 12, 55, vd.). Nog. erkli: iradeli (NRS, 1963: 438).

erlig: erkeklik (A 4/1). Nog. erlik: cesaret, kahramanlık (NRS, 1963: 439).

Nogay Türkçesi sözlüklerinde butlug sözcüğünün kök biçimi olan but sözcüğü bulunur.

Nogay Türkçesi sözlüklerinde çölgi sözcüğünün kök biçimi olan şöl sözcüğü bulunur.

Nogay Türkçesi sözlüklerinde ederlig sözcüğünün kök biçimi olan iyer sözcüğü bulunur.

Clauson ET elig sözcüğünü ellig madde başlı̆ı olarak almış ve sözcüğün çift -ll- ile olması gerektiğini belirtmiştir (ED: 141).

ET emig $[<e m-(i) g]$ sözcüğü ile NT emşek $[<e m-(i) s ̧-e-k]$ sözcüğünün anlamları ve kökleri aynı ancak türetilişleri farklı eklerle olmuştur. 
95. $\quad$ ew: ev, çadır (T 30, KT K 1, 8, BK D 32, 32, vd.). Nog. üy: ev (NRS, 1963: 387).

96. ̇ekegü: ikisi (birlikte)(KT K 3, ON 1; E 118/1). Nog. ekev: iki, iki tane (NRS, 1963: 431).

97. $\quad \dot{e} k^{23}$ : iki (KT D 27, 28, 36, KT K 2, 8, vd.). Nog. eki: eki (NRS, 1963: 432).

98. èkinti/èkinç: ikinci (KT D 33, KT K 5, BK G 1, vd.). Nog. ekinşi: ikinci (NRS, 1963: 432).

99. $\quad$ èkiz: ikiz (E 29/3; K-5, K-5). Nog. egiz: ikiz (NRS, 1963: 430).

10o. $\quad$ èl: ülke, yurt; halk (KT G 4, 8, 10, KT D 4, vd.). Nog. el: vatan; millet (NRS, 1963: 433).

101. èlçi: elçi (E 14/1, E 41/8, E 98/5, E 14/1, vd.). Nog. elşi: elçi, haberci (NRS, 1963: 434).

102. $\quad$ érkek: erkek (IrkB 24, 41). Nog. erkek: erkek (NRS, 1963: 438).

103. $\quad$ erte/erte ${ }^{24}$ : sabah; sonraki (O 7; E 45/1). Nog. erte: erken; sabah (NRS, 1963: 439).

104. gaşga 25 : alnı akıtmalı (at) (E 41/11). Nog. kaska: kel; beyaz alınlı (NRS, 1963: 153).

105. 2gaç: ağaç (BK G 11, T 25; IrkB 4, 56, 56, vd.). Nog. agaş: ağaç (NRS, 1963: 25).

106. $\quad$ mgaru ${ }^{26}$ : ileri, sonra, öte (ŞU K 10). Nog. arı: öte; daha uzak, ileri (NRS, 1963: 48-49).

107. rrak: $\operatorname{rrak}$, uzak (KT G 5, 7, BK K 4, 5, T 5). Nog. erek: uzak, ötede (NRS, 1963: 437).

108. $\quad$ t: köpek (BK G 10, Ta G 3, HT VII/1). Nog. iyt: it, köpek (NRS, 1963: 118).

109. iç: iç (BK G 14, KT G 12, BK K 14, Ta B 5, 6, vd.). Nog. iş: iç; karın (NRS, 1963: 121).

110. içgü: içecek (KarB I, IV/10). Nog. işki: içki (NRS, 1963: 121).

111. idi: sahip (IrkB 65). Nog. iye: sahip (NRS, 1963: 116).

112. idisiz: sahipsiz (KT D 19, 20 , BK D 16, 17). Nog. iyesiz: sahipsiz (NRS, 1963: 116).

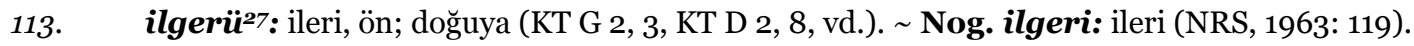

23 Clauson sözcüğ̈̈n orjinalinde $\dot{e} k k i$ şeklinde olduğunu belirtir. Clauson, Türk runik alfabesinin yazım ve imla kurallarının bir özelliği olarak çift ünsüzlerin tek bir harfle yazıldığı bilgisini verir ve buna örnek olarak da èkki "iki" sözcüğünü gösterir (ED: 100-101).

24 DLT’de (2015: 643) erte / irte sözcüğünün "sabahın erken saati” anlamında kullanıldığı görülmüştür. Clauson erte

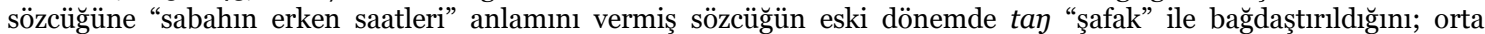
dönemde sözcügün iki karşıt anlamının ortaya çıktığını (1."yarınki sabahın erken saatleri; yarın” ve 2."bir andan daha erken”) belirtir. Clauson ayrıca sözcüğün bazen -n'li erten biçiminde kullanıldığını belirtir (ED: 202). NT'de erte sözcüğ̈̈ "erken, sabah" anlamında; erten sözcügü ise "yarın, sonraki” anlamındadır.

$25 \quad$ NT'de kaska biçiminde tanıklanan sözcügün ET'de gaşga biçiminde sözcük başında $g$ harfi ile yazılması ilginçtir. Aynı yazıtta (E 41) sözcük başında $g$ harfi ile yazılmış dört sözcük daha vardır: gün, gemçig, gerçin, geyik (Aydın, 2019: 141). Tekin'e göre bu örnekler, yazan kişinin diyalektinde hem ön hem de art $k$ sesinin ötümlüleşmeye başladığını göstermektedir (1999: 13).

26 Clauson ıngaru sözcüğünün ET'de ajaru/ınar//naru biçimlerinde de görüldüğünü; modern Türk dillerinde ise bazı ses değişikleriyle narl/nari/neri/arı/eri/agrı biçimlerinde yaşamını sürdürdüğünü belirtir (ED: 190). NT sözlüğ̈̈nde sözcüğün arı beri "ileri geri” biçiminde ikileme olarak da bulunduğu görülmüştür. 
114. ilk: ilk (T 23, KT D 32, BK D 30, 32, vd.). Nog. ilik: ilk, önce (Ergönenç, 2009: 110).

115. isig: sıcak; aziz, sevgili (IrkB 67). Nog. issi: sıcak (NRS, 1963: 121).

116. iş: iş, uğraş (KT D 8, 9, 10, 30, KT B, vd.). Nog. is: çalışma, iş, hizmet (NRS, 1963: 120).

117. kaç: kaç, ne kadar (T 20, 29). Nog. kaşav: kaç, ne kadar (NRS, 2018: 314).

118. kaçan: ne zaman; -dığı zaman (T 21). Nog. kaşan: ne zaman (NRS, 1963: 156).

119. kadın: kayın; kayınbirader (E 17/2). Nog. kayın: kayın; kayınbirader (NRS, 1963: 139).

120. kamış/kamuş: kamış, saz (ŞU G 1, IrkB 10, 38). Nog. kamıs: kamış (NRS, 1963: 143).

121. kan I: han, hükümdar (T 2, 2, 2, T 28, O 1 vd.). Nog. kan: han (NRS, 1963: 396).

122. kamı: hani (E 41/7, E 41/8). Nog. kana: hani, nerede (NRS, 2018: 289).

123. kanlkk: hanlık, hakana ait (IrkB 63, O. 1: A 2). Nog. kanlkk: hanlık (NRS, 1963: 396).

124. kanta: nerede. (E 41/8; IrkB 24). Nog. kayda: nerede (NRS, 1963: 137).

125. kantan: nereden (KT D 23, 23, BK D 19, 19). Nog. kaydan: nereden (NRS, 1963: 137).

126. kañu: hangi (KarB I, IV/3). Nog. kaysı: hangi (NRS, 1963: 138).

127. $\quad \boldsymbol{k a r a g u}^{\mathbf{2 8}}$ : gözetleme kulesi (T 34, T 53). Nog. karavıl: nöbet; bekçi (NRS, 1963: 147).

128. karşı: karşı, rakip (IrkB 19). Nog. karsı: karşı (NRS, 1963: 151).

129. kaş: kaş (KT K 11; E 26/9). Nog. kas: kaş (NRS, 1963: 153).

130. katıl-: katılmak (ŞU K 7, ŞU G 8). Nog. kat- 192: katmak, dahil etmek (NRS, 1963: 155).

131. katun: kağanın karısı (KT D 11, 25, KT K 9, vd.). Nog. katın: kadın (NRS, 1963: 396).

132. keçig: geçit (T 35; E 24/2, E 112, vd.). Nog. keçüv: geçme, geçiş (NRS, 1963: 165).

133. Kedim: zırh; giysi (KÇ 24, ŞU G 9; Or. 8212/76:A 12). Nog. kiyim: giyim(NRS, 1963:165).

134. kergeksiz: eksiksiz (KT K 12, BK G 11). Nog. kereksiz: gereksiz (NRS, 1963: 162).

\footnotetext{
${ }_{27} \quad$ ET ilgerü sözcüğü ilk sözcüğünün kısaltılmış ve yön bildiren halidir. Normalde “ileriye” anlamına gelir ancak yönlerin doğuya yüz döndürülerek belirlenmiş olduğu en erken dönemde "doğuya doğru” anlamına gelirdi. Sonradan zaman kavramı için "önce, evvel” anlamlarını karşlar olmuştur (ED: 144).

$28 \quad$ ET karagu sözcüğü ile NT’de ve diğer ÇKTL sözlüklerinde bulunan karavıl/karavul sözcükleri ilişkili olmalıdır. Temir, Moğolcadaki haragul "nöbetçi, bekçi, karakol” sözcüğü üzerine sözcüğün Çağataycada karaġul biçiminde; günümüz Kazak ve Kazan dillerinde karaul biçiminde benzer anlamlarla var olduğunu belirtir. Temir ayrıca Rusçada da aynı anlamda kullanılmakta olan karaul sözcüğünün Türkçeden alıntı olduğunu belirtir (2016: 70 not:3 ). Gülensoy Türkiye Türkçesindeki karakol sözcüğünün ET karagu sözcüğünden geldiğini ve sözcüğün Kıpçak Türk lehçelerinde karauıl biçiminde görüldüğünü belirtir (2007: 464).

29 ET katl- sözcüğünün NT sözlüklerinde kök biçimi bulunur.
} 
135. Kezig: sıra; nöbet (A 12). Nog. kezek: sıra, nöbet (NRS, 1963: 158).

136. Kezü: boyunca (ŞU D 6). Nog. kezüv: gezme, dolaşma (NRS, 1963: 158).

137. kèçe: gece (ŞU D 1; IrkB 1, 2, 22). Nog. keşe: gece (NRS, 1963: 164).

138. kèrü: geri; batıda (KT D 2, BK D 3, O 11, KÇ 6, vd.). Nog. keri: geri (NRS, 1963: 162).

139. kèyik: yaban hayvanı (T 8; E 28/7, E 44/2,vd.). Nog. kiyik: vahşi, yabani (NRS, 1963:165).

140. kzlıç: kılıç (Or. 8212/76: A 6, (B) A 10, 11-12, IrkB 8). Nog. kılış: kılıç (NRS, 1963: 200).

141. kzlınç: yapma, etme (ŞU K 12; T-8/2, T-14/2). Nog. kzluv3o: yapma (NRS, 1963: 199).

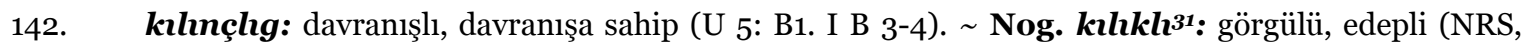
1963: 200).

143. kurıg: kıyı, kenar (E 72/2). Nog. kur: bozkır; kır; alan, tarla; kenar (NRS, 1963: 201).

144. kesga: kısa, az (KarB II/10). Nog. kzska: kısa (NRS, 1963: 202).

145. kış: kış (BK G 2). Nog. kes: kış (NRS, 1963: 202).

146. kışlag: kışlak (IrkB 51, 56). Nog. kıslak: kışlak (NRS, 1963: 203).

147. kiçig: küçük, az (KT G 3, 3, BK K 2, 3, vd.). Nog. kişkey322 küçük (NRS, 1963: 168).

148. kidiz: keçe (IrkB 33). Nog. kiyiz: keçe (NRS, 1963: 165).

149. kişi: kişi; adam (KT G 6, 7, 7, 7, KT D 1, vd.). Nog. kisi: kişi, adam (NRS, 1963: 167).

150. kişne-: kişnemek (A 80/2). Nog. kisine-: kişnemek (NRS, 1963: 167).

151. koñ: koyun (KT D 12, BK D 11, Ta D 9; E 2/4, vd.). Nog. koy: koyun (NRS, 1963: 167).

152. koñȩı: çoban (Or. 8212/76: (C) A 5). Nog. koyşı: çoban (NRS, 1963: 169).

153. koyuz: böcek (T II T 14: A 29). Nog. koyız: böcek (NRS, 1963: 173).

154. korkunç: korku, korkunç (IrkB 36). Nog. korkmmş̧: korkunç (NRS, 1963: 173).

155. Koş: (muvakkaten kullanılan) çadır (K-4). Nog. kos: geçici yurt (NRS, 1963: 174).

156. köyül: gönül (KT K 11, T 15, 32; KarB I, vd.). Nog. köyil: gönül; istek (NRS, 1963: 179). eylemden ad türeten eklerle olmustur. türeten eklerdir.

ET kılınçhı $[<k \imath l-(\imath) n c ̧+l ı g]$ sözcüğ̈ündeki $-n c ̧+$ eki ile NT kılıklı $[<k \imath l-(\imath) k+l \imath]$ sözcüğündeki $-k+$ eki farklı eylemden ad

Sözcükteki + key eki küçültme ekidir ancak bu ek kişkey sözcüğünde sözcük köküyle kalıplaşmıștır ve dolayısıyla sözcükte "küçücük" anlamı bulunmaz. NT’de kişkey sözcüğüne küçültme anlamı katılması için sözcüğe ikinci bir küçültme eki olan +kene eki getirilmelidir: kişkenekey "küçücük". 
157. köyüllüg: düşünceli (U 178: A 5-6). Nog. kögilli: gönüllü; istekli (NRS, 1963: 179).

158. köpük: köpük (IrkB 20). Nog. köbik: köpük (NRS, 1963: 176).

159. körrklüg: güzel, manzaralı (IrkB 64, 18). Nog. körkli: güzel (NRS, 1963: 180).

160. körksüz: güzel olmayan (Mainz 386:A 1). Nog. körksiz: güzel olmayan (NRS, 1963: 180).

161. kudruk: kuyruk (IrkB 50). Nog. kuyrkk: kuyruk; kalça (NRS, 1963: 186).

162. kugu: kuğu. (IrkB 35, 35). Nog. kuv 2: kuğu (NRS, 1963: 182).

163. kulkak: $k u l a k$ (BK K 11, BK G 12). Nog. kulak: kulak (NRS, 1963: 186).

164. kullug: kölesi olan (KT D 21, BK D 18). Nog. kullı: kullu (NRS, 1963: 186).

165. kulun/kuluy: tay (IrkB 24, A 78). Nog. kulın: tay (NRS, 1963: 187).

166. kumursga: karınca (IrkB 37). Nog. kumırska: karınca (NRS, 1963: 187).

167. kurtga: yaşlı kadın (IrkB 13). Nog. kurtka: yaşlı kadın (NRS, 2018: 385).

168. kurugsak: kursak, mide (IrkB 8). Nog. kursak: kursak, karın, mide (NRS, 1963: 188).

169. kuş: kuş (IrkB 15, 35, 43, 44, 44, vd.). Nog. kus: kuş (NRS, 1963: 190).

170. kutlug: kutlu, aziz (MT, Bö ö 1; E 19/1, E 114, vd.). Nog. kutlı: kutlu (NRS, 1963: 190).

171. kuzgun: kuzgun (IrkB 54, 14). Nog. kuzgmn: kuzgun (NRS, 1963: 185).

172. kü: ses; ün, şan (KT D 25, 25, 26, vd.). Nog. küy: nağme, ahenkli ses (NRS, 1963: 192).

173. küç: güç, kudret (KT D 8, 9, 10, 12, 30, vd.). Nog. küş: güç, kuvvet (NRS, 1963: 195).

174. küçlüg: güçlü (O 12; E 49/4; IrkB 3, 20, 60). Nog. küşli: güçlü (NRS, 1963: 196).

175. Küdegü: güvey (Ar 1; E 3/6). Nog. kiyev: güvey, damat (NRS, 1963: 165).

176. kümüss: gümüş (KT G 5, BK K 3, 11, T 48, vd.). Nog. kümis: gümüş (NRS, 1963: 193).

177. küni: hasetlik, kıskançlık (BK D 30). Nog. künşilik33: kıskançlık (NRS, 1963: 194).

178. künlük: günlük (Ta B 2, ŞU D 9). Nog. künlik: günlük (NRS, 1963: 194).

179. küntüz: gündüz (KT D 27, BK D 22, T 12, vd.). Nog. kündiz: gündüz (NRS, 1963: 191).

180. Iaçın: laçin (atmaca, doğan) (Or. 8212/76: (B) B 4). Nog. laşın: şahin (NRS, 1963: 206).

33 NT sözlüklerinde, ET küni "kıskançlık" sözcüğ̈̈nnün ek almış biçimi olan kün(i)+şi+lik "kıskançlık" sözcüğü ve sözcüğün eylem biçimi olan kün(i)le- "kıskanmak" sözcüğü bulunmaktadır. 
181. monçuk: kıymetli taş (T II T 14: A2-3). Nog. moyşak: boncuk; kolye (NRS, 1963: 225).

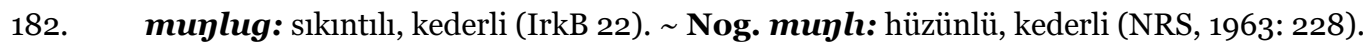

183. neke: niye, niçin (T 39, 39). Nog. nege: niye, niçin (NRS, 1963: 235).

184. nençe: nice, nasıl (BK K 9, 9). Nog. neşe: kaç (NRS, 1963: 237).

185. oglan: çocuklar (E 26/2, E 26/8; IrkB 23, vd.). Nog. ulan: erkek çocuk (NRS, 1963: 382).

186. ogr: hirsız (IrkB 16). Nog. urı: hırsız (NRS, 1963: 384).

187. ogul: çocuk (KT D 1, 5, BK D 2, 6, vd.). Nog. ul: çocuk, erkek çocuk (NRS, 1963: 379).

188. ol: üçüncü teklik kişi zamiri (KT D 16, 21, 24, 25, 32, vd.). Nog. o: o (NRS, 1963: 239).

189. onunç: onuncu (BK G 10, ŞU B 2, HT XVI/1, vd.). Nog. ontnşı: onuncu (NRS, 1963: 247).

190. ordo: ordugah (KT K 8, 9; IrkB 28, 34). Nog. orda: karargah, ordu (NRS, 1963: 248).

191. orto: orta (BK K 11, 11, KT G 2, 2, BK K 2, vd.). Nog. orta: orta (NRS, 1963: 251).

192. otuz: otuz (KT G 1, KT D 4, 14, 18, 32, vd.). Nog. otzz: otuz (NRS, 1963: 253).

193. oynag: gönül eğleyici (Mainz 403a,b: (B) B 10). Nog. oynak: oynak (NRS, 1963: 242).

194. öç: kin (Mainz 386: B 3-4). Nog. öş: öç, intikam (NRS, 1963: 264).

195. öd II: gönül, iç; öd, safra kesesi, dalak (BK D 29). Nog. öt: öd, safra (NRS, 1963: 262).

196. ögsüz: öksüz (KT K 9; E 45/2). Nog. öksüz: öksüz, annesiz (NRS, 2018: 501).

197. ̈gür: sürü (IrkB 56). Nog. üyir: sürü (NRS, 1963: 388).

198. ̈künç: pişmanlık (E 68/22, E 42/7, E 28/2, vd.). Nog. ökiniş: pişmanlık (NRS, 1963: 257).

199. ̈̈künçlüg: üzüntülü, pişman (T-8/2). Nog. ökinişli: pişman, üzüntülü (NRS, 1963: 257).

200. ̈kӥz: öküz (E 48/4; E 10/2; T-13/6; IrkB 25, vd.). Nog. ögiz: öküz (NRS, 1963: 255).

201. ̈lüg: ölü, cenaze (KT K 9, İA-a 1; E 26/2). Nog. öli: ölü (NRS, 1963: 258).

202. ölüm: ölüm, ecel (IrkB 13, 17, 49, 49). Nog. ölim: ölüm (NRS, 1963: 258).

203. örtçe: ateş gibi (T 40). Nog. ört: yangın, alev (NRS, 1963: 262).

204. öt: öğüt, nasihat (IrkB 58). Nog. ögit: öğüt, telkin (NRS, 1963: 255). 
205. $\quad$ öz 2: vadi (Aç I 1; E 3/1, E 7/4, E 10/1, E 26/4, vd.). Nog. özen34: vadi (NRS, 1963: 256).

206. ̈zlük: özel, hususi (BK G 12, KÇ 4, 15,vd.). Nog. özlik: bireysel, hususi (NRS,1963: 256).

207. saç: saç (BK G 12; E 26/11; 26/7). Nog. şaş: saç (NRS, 1963: 407).

208. saya: sana (T 32). Nog. saga: sana (NRS, 1963: 282).

209. sarıg: $\operatorname{sarl}($ BK K 11, T 48; E 41/5; IrkB 11, vd.). Nog. sarı: sarı (NRS, 1963: 289).

210. satıgçı: satıcı (Mainz 388: A 3). Nog. satuvşı: satıcı (NRS, 1963: 290).

211. sekiz: sekiz (BK D 14, 24, 26, BK G 2, Ta D 3, vd.). Nog. segiz: sekiz (NRS, 1963: 292).

212. sekizinç: sekizinci (ŞU D 5, 6, ŞU G 6, vd.). Nog. segizinşi: sekizinci (NRS, 1963: 292).

213. seviglig: sevgili (A 88/2). Nog. süyikli: sevgili (NRS, 1963: 314).

214. siçgan: fare (A 47). Nog. şışkan: fare (NRS, 1963: 424).

215. $\quad$ smuk: kırık (IrkB 48). Nog. smek: kırık, kırılmış (NRS, 1963: 321).

216. sıykur: şahin (E 71/3; Or. 8212/1692:A Sol 2-3, 11). Nog. suykar: şahin (NRS,2018: 585).

217. sigil: kız kardeş(KT D 20,BK D17; Körü I, YÇ I,II). Nog. sinli: kız kardeş(NRS,1963: 398).

218. suw: su, akarsu (KT D 27, BK D 16, 17, 22, 35, vd.). Nog. suv: su (NRS, 1963: 309).

219. suwsuz: çorak yer, çöl (BK G-D; IrkB 45). Nog. suvsız: susuz (NRS, 1963: 311).

220. süyüg: mizrak (KT D 35, BK D 26, T 28). Nog. süngi: süngü (NRS, 1963: 315).

221. sü̈ük: kemik (BK D 20, KT D 24). Nog. süyek: kemik (NRS, 1963: 313).

222. tag: dağ (KT D 24, 26, BK D 20, BK G 8, BK B 5, vd.). Nog. tav: dağ (NRS, 1963: 324).

223. tagıku: tavuk (Tes B, Ta G 2, ŞU K 10, ŞU B 4). Nog. tavık: tavuk (NRS, 1963: 325).

224. takı: daha, henüz (IrkB 3, 33). Nog. tagı: daha (NRS, 1963: 325).

225. taltm 35: yırtıcı (IrkB 3, 40, 43, 51). Nog. talav: talan, yağma (NRS, 1963: 329).

226. tamka: damga (E 41/4). Nog. tamga: damga (NRS, 1963: 332).

34 Clauson ET’de bulunan özen 2 "nehir, vadi” sözcüğünün öz 2 "vadi” sözcüğüyle ilişkili olduğunu belirtir (ED: 289). NT sözlüklerinde "vadi” anlamda özen sözcüğü bulunmaktadır.

35 Müller (1911: 81) ve Yıldırım (2017: 131) vahşi hayvanları niteleyen tahm sözcügünün tala- "yaralamak, incitmek; soygun yapmak, yağma yapmak” sözcüğünün başka bir biçimi olan tah- eyleminden türediğini belirtir. Tekin bu eylemin Uygurca metinlerde çoğunlukla tala- biçiminde geçtiğini, nadir olarak tah- biçiminde görüldüğünü belirtir (2019: 36). NT'de tala- eylemi "parçalamak, yırtmak, yaralamak, talan etmek" anlamlarında bulunmaktadır. ET talım $(<$ talı-m) sözcüğü ile NT talav (<tala-v) sözcüğü farklı eylemden ad türeten ekler almıştır. 
227. tamkalng: damgalı (E 26/6; Or. 8212/78: A 2). Nog. tamgalı: damgalı (NRS, 1963: 332).

228. tanuklug: tanıklı, şahitli (Or. 8212/78: A 2). Nog. tamıklı: tanıklı (NRS, 1963: 333).

229. tapa: -a/-e doğru (KT D 28, 31, vd.). Nog. tabagan/tamagan ${ }^{36}$ : -a/-e doğru (NRS, 1963: $323 / 330)$.

230. tarrg: ekin ( IrkB 53). Nog. tarı: darı (NRS, 1963: 338).

231. tariglag: tarla (Ta B 4). Nog. tarlav: tarla, alan, saha; kır; sahra (NRS, 1963: 336).

232. tarkınç: dağınık (T 22). Nog. tarkav37: dağınık (NRS, 1963: 336).

233. $\operatorname{taş}^{38}$ : taş, kaya, yazıt (KT G 11, 12, 12, 13, KT K 13, vd.). Nog. tas: taş (NRS, 1963: 338).

234. taş: dış (T 4, KT G 12, BK K 14, T 13, ŞU G 4, vd.). ths: dış; üst (NRS, 1963: 376).

235. tathghg: tatll, lezzetli (U 5: (B1. I) A 6). Nog. tath: tatll (NRS, 1963: 337).

236. tawar: mal, mülk, servet (ŞU G 5; Ç 1). Nog. tovar: mal (NRS, 1963: 354).

237. tawışgan: tavşan (T 8, ŞU D 8; IrkB 44, 44). Nog. tavşan: tavşan (NRS, 1963: 325).

238. teg39: gibi (KT D 5, 5, 12, 12, 31, vd.). Nog. dey: gibi.

239. tegi40: ${ }^{4 a d a r}\left(K_{T} ~_{3}, 3,4,4,4\right.$, vd.). Nog. deyim: kadar (NRS, 1963: 99).

240. tegül: değil (Mainz 403a,b: (B) B 6). Nog. tuvıl: değil (NRS, 1963: 364).

241. tegrük: yuvarlak (veya dönen) (A 80/1). Nog. tögerek: yuvarlak; çevre (NRS, 1963: 359).

242. teyri: gök; aziz (KT G 9, KT D 1, 11, vd.). Nog. tangiri: Tanrl, Allah (NRS, 2018: 631).

243. teriy: derin; tabak (A 3/1). Nog. teren: derin (NRS, 1963: 346).

244. ters: ters; güç, zor (E 38/2). Nog. teris: ters; yanlış (NRS, 1963: 347).

245. teve: deve (IrkB 5, 46). Nog. tüye: deve (NRS, 1963: 367).

246. thl41: muhbir; dil(T 32, 36, ŞU D 12,ŞU B 6; Mainz 403a,b:B). Nog. til: dil(NRS,1963:350).

\footnotetext{
$36 \quad$ Ağılarda bu sözcük tabaan/tamaan biçiminde telaffuz edilir.

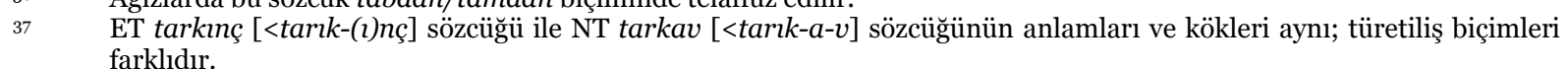
Tekin sözcügün uzun ünlülü olduğunu belirtir (1995: 90).

39 Gabain $t A g$ sözcügün̈ün Eski Türkçede "eşitlik, gibilik" bildirdiğini ve bir son çekim edatı olduğunu belirtir. Gabain, edatın çoğunlukla bir önceki sözcükten ayrı yazıldığını, nadiren önceki sözcüğge eklendiğini belirtir (1988: 105). Eski Türkçedeki $t A g$ edatı NT’de çoğunlukla önceki sözcüğe ekleşerek -DAy, -DIy, -DOy biçiminde kullanılmaktadır.

40 Clauson tegi edatının teg- "değmek, ulaşmak" eylemine zarf-eylem eki getirilerek türetildiğini ve sözcüğün sonraları tegin biçiminde söz sonu - $n$ ile de kullanıldığını belirtir (ED: 477-478).

${ }_{41} \quad$ Clauson thl sözcüğüne "dil” anlamını vermiş ve sözcügüü dolayll olarak "bilgilendirici, bilgi, özellikle gizli bilgi, konuşulan dil” anlamlarını da barındırdı ğını belirtmiştir (ED: 489).
} 
247. trryak: tirnak (IrkB 44, 44). Nog. thrnak: tırnak (NRS, 1963: 375).

248. tilkü: tilki (IrkB 46). Nog. tülki: tilki (NRS, 1963: 370).

249. tirig: diri (KT G-D, KT K 9, HT VI/2; E 3/3, vd.). Nog. tiri: diri, canlı (NRS, 1963: 352).

250. toguru: dosdoğru, doğrudan (ŞU G 5). Nog. tuvra/tuvrı: doğru (NRS, 1963: 364).

251. tokuz: dokuz (KT G 2, 3, KT D 14, KT K 6, 9, vd.). Nog. togrz: dokuz (NRS, 1963: 354).

252. tokuzunç: dokuzuncu(KT K-D; ŞU B 3, vd.). Nog. togızınşı: dokuzuncu(NRS, 1963: 354).

253. tonlug: giyimli (KT D 29, BK D 23; IrkB 22, vd.). Nog. tonlı: kürklü (NRS, 1963: 357).

254. tonsuz: sırtı açıkta (olan) (KT D 26, BK D 21). Nog. tonsız: kürksüz (NRS, 1963: 357).

255. toyuz: domuz (KÇ 18; E 98/3; IrkB 6, 6). Nog. dogız: domuz (NRS, 1963: 101).

256. torug: doru renkli at, doru (KT D 33, Su 7; A 80/3). Nog. torı: kızll (at) (NRS, 1963: 358).

257. töpö: başın üst bölümü; tepe (KT D 11, BK D 10). Nog. töbe: tepe; yüce (NRS, 1963: 359).

258. törö: töre, yasa (KT D 3, 16, 16, 30, vd.). Nog. töre: adalet; yasa (NRS, 1963: 361).

259. tört: dört (KT D 2, 2, KT G-B, BK K 9, 9, vd.). Nog. dört: dört (NRS, 1963: 101).

260. törtünç: dördüncü (KT K 6, BK D 31, vd.). Nog. dörtinşi: dördüncü (NRS, 1963: 102).

261. tug: tuğ, sancak (ŞU D 5, ŞU G 9, ŞU B 3, 6). Nog. tuv: tuğ (NRS, 1963: 363).

262. turña: turna. (E 48/5; IrkB 61). Nog. turna: turna (NRS, 1963: 366).

263. tuş²: eşit, eş değer (ŞU G 1). Nog. tus: yön; karşı taraf (NRS, 1963: 366).

264. tutsık: tutacak (KT G 4, 10, BK K 3, 8). Nog. tutkış43: tutacak, sap (NRS, 1963: 366).

265. tuyug: toynak (IrkB 5). Nog. tuyak: toynak (NRS, 2018: 668).

266. tü: tüy. (Kağıda Yz: IrkB 3). Nog. tük: tüy; kıl (NRS, 1963: 369).

267. tügünlüg: düğümlü (T 54). Nog. tüyinli: düğümlü (NRS, 1963: 369).

268. türlüg: türlü(Mainz 403a,b:(B) A 1, T II T 14: A2, vd.). Nog. türli: türlü (NRS, 1963: 371).

269. tütünçsüz: dumansız (Or. 8212/78: (B) A 3). Nog. tütinsiz: dumansız (NRS, 1963: 373).

\footnotetext{
42 Clauson ET tuş sözcüğünün temel olarak "eşit, eşdeğer" dolayısıyla "karşıt, karşı karşıya" anlamında olduğunu, çağdaş Türk dillerinde bu ve genişletilmiş bazı anlamlarla yaşadığını belirtir (ED: 558). Aydın, ŞU G 1'deki cümleye göre sözcüğ̈̈ "iki ırmağın birleşme yerinde oluşan geniş ve derin havuz" şeklinde anlamlandırmayı daha uygun görür (2018b: 185).

43 ET tutsık (<tut-sık) sözcüğü ile NT tutkış (<tut-kış) sözcüklerinin kökü aynı ancak ekleri farklıdır.
} 
270. uç: uç; kanat; son; hedef (T 40, Ta B 5, 5, 5, 5, vd.). Nog. uş: uç (NRS, 1963: 385).

271. ulug: ulu, yüce (KT D 28, 34, 34, 40, vd.). Nog. ulh: ulu, büyük (NRS, 1963: 382).

272. urug44: soy sop; tohum (KarB I, IV/6). Nog. urkk/urlkk: tohum (NRS, 1963: 384, 383).

273. uruş: savaş (O 10; E 99). Nog. urts: savaş, muharebe; dövüş (NRS, 1963: 384).

274. Us: akıl (T 19). Nog. es45: bellek, akıl (NRS, 1963: 439).

275. utuş: uğur, yol (E 10/9). Nog. utss: kazanç; ikramiye (NRS, 1963: 385).

276. uzun: uzun (IrkB 42, 47, Mainz 403a,b: (B) A 1-2, vd.). Nog. uzın: uzun (NRS,1963: 380).

277. üç: üç (KT D 4, 18, BK D 15, 32, 34, vd.). Nog. üş: üç (NRS, 1963: 392).

278. ̈çegü: üçü birlikte (T 21). Nog. üşev: üç tane (NRS, 1963: 392).

279. ̈çün: için (KT G 9, 9, 9, KT D 3, 6, vd.). Nog. üşin: için (NRS, 1963: 392).

280. ̈çünç: üçüncü (KT D 33, KT K 6, Ç 1, vd.). Nog. üşinşi: üçüncü (NRS, 1963: 392).

281. ülüg46: bölüm, pay (T 4, KT D 29, BK D 23, vd.). Nog. ülis: pay, hisse (NRS, 1963: 389).

282. üze: üstte, yukarıda (KT D 1, 1, 10, 16, 17, vd.). Nog. ̈̈st47: üst, üzeri (NRS, 1963: 391).

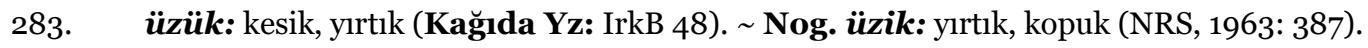

284. ya: yay (Mainz 400: A 4). Nog. yay: yay (NRS, 1963: 457).

285. yadag: yaya (BK D 32, BK G 1, T 4, KT D 28, vd.). Nog. yayav: yaya (NRS, 1963: 474).

286. yagı: düşman (KT D 2, 9, 10, 14, 14, vd.). Nog. yav 2: düşman (NRS, 1963: 453).

287. yagıçı: savaşçı (T 50; E 44/2). Nog. yavşı: ara bulucu (NRS, 1963: 453).

288. yaguk: yakın (KT G 7, BK K 5). Nog. yovrk: yakın (NRS, 1963: 445).

289. yakılıg: taraflı (E 65/3). Nog. yaklı: taraflı (NRS, 1963: 458).

44 Clauson ET urug sözcüğünün aslında "tohum, çekirdek" anlamında olduğunu ancak anlamsal ilişkilerle sözcüğün "döl, soyundan gelen, klan" anlamlarını da taşıdığını belirtir (ED: 214).

45 Eren, eski ve yeni Türk diyalektlerinde bulunan (Tkm es. - Nog es. - Kzk es. - Krg es. - Cuv as. vb.) “akll” anlamına gelen as/es/is sözcüklerinin Batı Türklerinin dilinde yaşayan us sözcüğüyle ilişkili olmadığını belirtir (1999: 425). Eren bu görüşünün nedenini açıklamaz. Gülensoy, us sözcüğü maddesinde sözcüğün $\hat{u}$ - "anlamak" kökünden türediğini belirtir. Ayrıca sözcüğün Türk lehçelerinde es/äs/is şeklinde de yaşadığını belirtir (2007: 971). ET sözcüklerdeki /u/ sesinin NT ve diğer ÇKTL'deki bazı sözcüklerde /a/, /e/, /i/ seslerine dönüşebildiği (ör: boguz>bogaz, sıłkur $>$ sunkar, yogun>yugan, bışur>pisir-) düşünüldüğünde, ET us "akıl” sözcüğü ile NT es “akıl” sözcüğünün ilişkili olması mümkün görünmektedir.

46 ET ülüg sözcüğ̈̈ modern dönemde eş anlamlısı olan ülüş "pay, hisse” sözcüğünden daha nadir kullanılır (ED: 142). Sözcüklerde üle- "paylaştırmak" eylemine gelen eylemden ad türeten ekler farklıdır.

47 Tekin (2003: 135) ve Gülensoy (2007: 997) Türk dillerindeki üst sözcüğünün ET üz “üst” sözcüğünden türediğini belirtir. 
290. yalyus/z: yalnız (KÇ 23, E 16/1, E 68/17, vd.). Nog. yalgız: yalnız (NRS, 1963: 460).

291. yaraklng: silahlı (KT D 23, 32, BK D 19, T 54). Nog. yarak $^{48}$ : silah (NRS, 1963: 467).

292. yarm II: kürek kemiği, omuz (IrkB 40). Nog. yavırm: omuz (NRS, 1963: 454).

293. yartımlık49: ayrı, ayrılmış (Or. 8212/77: A 6). Nog. yartı: yarı, yarım (NRS, 1963: 469).

294. yaruk: 1 şık (ŞU D 1, DU II 1; T-6/3; IrkB 26, vd.). Nog. yarık: aydınlık(NRS, 1963: 469).

295. yaş I: göz yaşı; taze (KT K 11; IrkB 17, vd.). Nog. yas 3: yaş, göz yaşı (NRS, 1963: 470).

296. yaş II: yaş, (ömür) (KT D 30, BK D 14, 24, vd.). Nog. yas 1: yaş (ömür) (NRS, 1963: 469).

297. yaşıl: yeşil (IrkB 51, T II T 14: A 26-27). Nog. yasıl: yeşil (NRS, 1963: 471).

298. yavaş: nazik, llımlı (Or. 8212/77: A 3-4). Nog. yuvas: sakin, halîm (NRS, 1963: 444).

299. yay: yaz (BK B 3, BK D 39, ŞU D 8). Nog. yaz: yaz (NRS, 1963: 455).

300. yaylag: yayla (Ta B 5, IrkB 62, 51, 56). Nog. yaylak: yayla; yazlık (NRS, 1963: 457).

301. yaz: ilkbahar (BK G 2, KT K 8, BK D 31). Nog. yay 2: bahar, ilkbahar (NRS, 1963: 457).

302. yazuklug: günahl, kabahatli (ŞU D 2). Nog. yaznk: kabahat, suç; günah (NRS, 1963: 456).

303. yegren: kestane rengi(KÇ 15, 21; AÖ-2, vd.). Nog. yiyren: kestane rengi(NRS, 2018: 237).

304. yemçi: yemci, azıkçı; mec. kısmeti, payı, ...veren (İl). Nog. yem5o: yem (NRS, 1963: 106).

305. yemiş: meyve; mec. kısmetli, bahtlı (YT). Nog. yemis: meyve; yemiş (NRS, 1963: 106).

306. yègen: yeğen (HT VII/3, Ar 1, Su 8, Ç 3, vd.). Nog. yiyen: yeğen (NRS, 1963: 123).

307. yégirmi: yirmi (KT D 11, 15, 18, 28, 31, vd.). Nog. yırma: yirmi (RNS, 1956:143).

308. yégirminç: yirminci (ŞU G 1, 11, U 179: B 3). Nog. yrrmanşı: yirminci (RNS, 1956:143).

309. yèl: yele (IrkB 16). Nog. yal: yele (NRS, 1963: 458).

310. yèr: yer, yeryüzü (KT G 4, 4, 9, 9, vd.). Nog. yer: toprak, arazi; dünya (NRS, 1963: 106).

311. yèti: yedi (KT D 11, 13, 13, 15, 30, vd.). Nog. yeti: yedi (NRS, 1963: 107).

312.

yétinç: yedinci (KT K 5, O 12, Ta D 7, vd.). Nog. yetinşi: yedinci (NRS, 1963: 107).

48 Sözcügün $+l I$ addan ad türeten eki almış biçimi NT sözlüklerinde bulunmaz.

49 Hapaks legomenon olan sözcük NT'de ve diğer Türk dillerinde bulunan yartı "yarı, yarım; yırtık" sözcüğü ile ilişkili olmalıdır.

5o Sözcügüün $+s ̧ I$ addan ad türeten eki almış biçimi NT sözlüklerinde bulunmaz. 
313. yètmiş: yetmiş (KT D 12, BK D 11, Tes K 5, vd.). Nog. yetpis: yetmiş (NRS, 1963: 108).

314. yılıg: sıcak, llık; yumuşak mizaçlı (IrkB 2). Nog. yılı: sıcak, llık (NRS, 1963: 128).

315. yımşak: yumuşak (KT G 5, 5, 6, BK K 4, vd.). Nog. yumsak: yumuşak (NRS, 1963: 448).

316. yilig: ilik; kemik (YÇ I, YÇ II). Nog. yilik: ilik (NRS, 1963: 123).

317. yinçge: ince. (Moğolistan Y: T 13, 13). Nog. yigişke: ince (NRS, 1963: 124).

318. yogun: kalın (BK G 15, T 14). Nog. yuvan: kalın (NRS, 1963: 444).

319. yokaru/yügerü: yukarı (T 25, BK D 2, 10, vd.). Nog. yogarı: yukarı (RNS, 1956: 66).

320. yolagçı: öncü birlik (?) (BK G-D). Nog. yolavşı: yolcu (NRS, 1963: 124).

321. yolı: kez, defa (KT D 15, KT K 4, BK D 13, vd.). Nog. yol 2: kez, sefer (NRS, 1963: 124).

322. yultuz: yıldız (U 5: (B1. II) A 8-9, B 7-8, vd.). Nog. yuldız: yıldız (NRS, 1963: 447).

323. yumuş: elçi; iş, hizmet. (E 152/1). Nog. yumes: iş, yumuş (NRS, 2018: 799).

324. yuyka: ince, yoğunluğu az (T 13, 13, KarB II/7). Nog. yuka: ince (NRS, 1963: 447).

\section{2. Eylemler}

1. $\quad$ aç- I: açmak (T 28, Ç 4). Nog. aş-: açmak (NRS, 1963: 54).

2. $\quad$ aç- II51: acıkmak (BK K 6). Nog. aşık-: acıkmak (NRS, 1963: 55).

3. $\quad$ adır-: ayırmak; öldürmek (E 28/8; K-11). Nog. ayır-: ayırmak (NRS, 1963: 31).

4. adrıl-: ayrılmak (BK G 7, T 2, O 12, İA-a 1, vd.). Nog. ayırıl-: ayrılmak (NRS, 1963: 32).

5. agrı-: hastalanmak (BK G 9, YU 1). Nog. avrr-: hastalanmak, ağrımak (NRS, 1963: 24).

6. akıt-/akız-5²: akın ettirmek; akıtmak (KT K 8, T 35, Tes K 3, Ta D 2). Nog. agıst-: akıtmak, boşaltmak (NRS, 1963: 26).

7. alıt-: yakalatmak; aldırtmak (E 28/6). Nog. aldert-53: aldırtmak; getirtmek (NRS, 1963: 38).

8. ar-: yorulmak, bitap düşmek (T-5/1). Nog. arn-: yorulmak, bitmek (NRS, 1963: 48).

9. $\quad$ aş-: aşmak, geçmek (KT D 17, BK D 15, vd.). Nog. as-: aşmak, geçmek (NRS, 1963: 50).

10. atan-: atanmak; denmek(Ta G 6, Ta B 1, vd.). Nog. atal-54: adlandırılmak (NRS, 1963: 52).

${ }_{51} \quad$ Clauson (ED: 19) ve Tekin (1995: 90) aç- II sözcügünün ünlüsünü uzun olarak belirtir.

$5^{2}$ Aynı anlamı taşıyan ET akıt- ve akzz- sözcükleri -(l)t- , -(l)z- olmak üzere farklı ettirgen çatı ekleriyle türetilmiş sözcüklerdir. NT agıst- sözcüğ̈̈ -(l)st- ettirgen çatı ekiyle türetilmiştir.

53 aldırt- sözcügüüne - dır- ve - $t$ - ettirgenlik ekleri getirilerek sözcügüün geçişlilik derecesi arttırılmıştır. 
11. atlat-: ata bindirmek (T 25). Nog. atlander-55: ata bindirmek (NRS, 1963: 53).

12. awla-: avlamak (KÇ 9). Nog. avla-: avlamak (NRS, 1963: 22).

13. ba-: bağlamak (T 27; IrkB 14, 14, 18, 33, vd.). Nog. bavla-56: bağlamak (NRS, 1963: 64).

14. ban-: bağlanmak (E 3/2, E 10/5). Nog. bavlan-: bağlanmak (NRS, 1963: 64).

15. basın-: baskın yemek, yenilmek (T 39; IrkB 46). Nog. basıl-: basılmak (NRS, 1963: 73).

16. başla-: baş olmak, önder olmak (E 45/4; E 32/12; Or. 8212/77: A 3). Nog. basla-: başlamak (NRS, 1963: 72).

18. bed(i)ze-: bezemek, süslemek (İA-ö 2, İA-ö 3; A 43, A 44). beze-: süslemek (NRS, 1963: 75).

19. bedizet-: süsletmek (KÇ 24, KT G 11, A78, vd). Nog. bezeklet-: süsletmek(NRS, 1963: 75).

20. bedizle-: süslemek (IrkB 28). Nog. bezekle-: süslemek (NRS, 1963: 75).

21. bèr-: vermek (KT D 1, 1, 8, 25, BK D 21, vd.). Nog. ber-: vermek (NRS, 1963: 78).

23. buşur-: pişirmek (U 179: A 2). Nog. pisir-: pişirmek (NRS, 1963: 268).

24. bin-: binmek (KT D 32, 33, 33, 36, 37, vd.). Nog. min-: binmek (NRS, 1963: 224).

25. bintür-: bindirmek (T 25). Nog. mindir-: bindirmek (NRS, 1963: 223).

26. biş-: pişmek, olgunlaşmak (IrkB 53). Nog. pis-: pişmek (NRS, 1963: 269).

27. boşun-: kurtulmak, serbest kalmak (ŞU D 7). Nog. bosan-: boşanmak (NRS, 1963: 85).

28. buluş-: birlikte bulmak (U 5: (B1.II) B 4-5). Nog. bolıs-: yardımlaşmak (NRS, 1963: 84).

29. buyad-: bunalmak (T 26). Nog. muyay-: üzgün olmak (NRS, 1963: 228).

30. buzagula-: buzağılamak (IrkB 41). Nog. buzavla-: buzağılamak (NRS, 1963: 89).

31. egir-: kuşatmak (KT K 6, 7, BK D 31, E 43/3). Nog. iyir-: eğirmek (NRS, 1963: 117).

32. esne-: esnemek (IrkB 10). Nog. esine-: esnemek (NRS, 1963: 441).

33. esre-: beslemek, büyütmek (E 50/2). Nog. asıra-: beslemek, büyütmek (NRS, 1963: 51).

ET atan- sözcüğü -n-; NT atal- sözcüğü ise -l- edilgen çatı ekiyle türetilmiștir.

ET atlat- sözcüğü <at+la-t- biçiminde, NT atlandar- sözcüğü <at+la-n-drr-biçiminde türetilmiștir.

Clauson (ED: 314-315) ve Gülensoy (2007: 104) bağla- sözcügünün $b a$ - eyleminden $b a-\breve{g}+l A$ - biçiminde türetildiğini belirtir. Bu durum NT bavla- sözcügüu için de geçerlidir. 
34. ewir-: çevirmek, döndürmek. (BK D 25, T 26, 28). Nog. üyir-: çevirmek (NRS, 1963: 388).

35. ewle-: evlendirmek (Su 6; E 68/6). Nog. üylen-: evlenmek (NRS, 1963: 388).

36. ėşid-/èçid-: işitmek (KT G 2, T 12, 17, 22, 23, vd.). Nog. esit-: işitmek (NRS, 1963: 441).

37. ìt-: düzenlemek; etmek (KT D 21, 21, BK D 17, 18, vd.). Nog. et-: etmek (NRS, 1963: 443).

38. iç-: içmek (E 82; IrkB 17). Nog. iş-: içmek (NRS, 1963: 122).

39. kaç-: kaçmak; at koşturmak (O 9; YU 1, Ö I 1). Nog. kaş-: kaçmak (NRS, 1963: 156).

40. kah-57: havaya yükselmek (IrkB 35, 44). Nog. $k a l k$-: su yüzüne çıkmak; yükselmek (NRS, 1963: 141).

41. Karı-: yaşlanmak (KÇ 3). Nog. $\boldsymbol{k a r t a y - 5 8}^{8}$ : yaşlanmak (NRS, 1963: 151).

42. katnglan-: katılaşmak (Su 9; E 10/7, vd.). Nog. katıvlan-: katı olmak (NRS, 1963: 156).

43. kauvş̧-: kavuşmak (T 12, 20, 21, ŞU D 11, vd.). Nog. kavıs-: kavuşmak (NRS, 2018: 263).

44. kay-: geri dönmek. (E 28/2). Nog. kayt-: geri dönmek (NRS, 1963: 139).

45. $\quad$ kaz-: kazmak (A 80/4). Nog. kazt-: kazmak (NRS, 1963: 136).

46. kazgan-: kazanmak (BK D 13, 18, 22, vd.). Nog. kazan-: kazanmak (NRS, 1963: 135).

47. keç-: geçmek (BK D 26, 27, T 25, 38, 44, vd.). Nog. keş-: geçmek (NRS, 1963: 165).

48. keçür-: geçirmek (Irmak, göl vs.) (ŞU G 12). Nog. keşir-: geçirmek (NRS, 1963: 165).

49. kelür-: getirmek (BK G 11, 12, 15, T 36, vd.). Nog. keltir-: getirmek (NRS, 1963: 159).

50. $\quad$ kzd-: kıymak, öldürmek (KT G 6, BK K 4). Nog. kxy-: kıymak, kesmek (NRS, 1963: 198).

51. kılıçla-: kılıçla kesmek (KT K 5). Nog. kılışla-: kılıçlamak (NRS, 1963: 200).

52. kışla-: kışlamak (BK D 31, KT K 8, ŞU D 7). Nog. kısla-: kışı geçirmek (NRS, 1963: 203).

53. kigür-59: girdirmek (KÇ 20, KT D 23, BK D 19). Nog. kirgiz-: girdirmek(NRS,1963: 166).

54. kişe-: kösteklemek (IrkB 39). Nog. kisenle-: zincirlemek, kösteklemek (NRS, 1963: 167).

ET kalı- sözcüğü ile günümüz Türk dillerinde bulunan kalk-/kalık-/kalkı- sözcükleri arasındaki ilişki şüphelidir. Şayet ilişkili ise - $k$ - eylemden eylem türeten ekle türetilen kork- "korkmak" < korl- "korumak" ve basık- "bastırmak" < bas"basmak" sözcüklerine benzer bir morfolojik durum olmalıdır. Gülensoy, hem kalk- "yukarı doğru yükselmek" sözcüğünün hem de kalkı- "slçramak, hoplamak" sözcüğünün ET kalı- "yükselmek" eyleminden türediğini belirtir (2007: 455).

$58 \quad$ Gülensoy, kart "yaşlı" sözcügünün kart- "yaşlanmak" eylemine eylemden ad türeten - $t$ eki getirilerek oluştuğunu belirtir (2007: 471). Öner'in (2013: 60) ve Buran (vd.)'ın (2014: 56) ÇKTL'de + ay- addan eylem türeten ekine verdiği örnekler arasında kartay- "yaşlanmak" sözcüğü bulunmaktadır. Dolayısyla NT kartay- sözcüğü ET kart- eyleminden türemiştir.

59 Clauson ET kigür- sözcüğünün kökünün kir- eylemi olduğunu ve sözcüğün Türk dillerinde kirgiz-, girdir- biçimlerinde yaşadığını belirtir (ED: 712). 
6o. köçür-: göçürtmek, göç ettirmek (IrkB 34). Nog. köşir-: göçürmek (NRS, 1963: 183).

61. körüş-: görüşmek (IrkB 15). Nog. köris-: görüşmek (NRS, 1963: 180).

62. kötür-: kaldırmak (KT D 11, 25, BK D 10, 21). Nog. köter-: kaldırmak (NRS, 1963: 182).

63. közed-: gözetmek (KT B). Nog. küzet-: gözetmek; korumak (NRS, 1963: 191).

64. Kulunla-: (at) yavrulamak (IrkB 5). Nog. kulınla-: tay doğurmak (NRS, 1963: 187).

65. kuwra-: bir araya gelmek (KÇ 27; Bö ö 4). Nog. kura-: toplamak (NRS, 1963: 187).

66. kuwrat-: toplamak, derlemek (ŞU K 5). Nog. kurat-: toplatmak (NRS, 1963: 188).

67. müyre-: böğürmek (IrkB 60). Nog. müyire: böğürmek (NRS, 1963: 229).

68. odgur-6o: uyandırmak (IrkB 20). Nog. uyat-: uyandırmak (NRS, 1963: 386).

69. okı-61: çağırmak, davet etmek(BK D 28). Nog. oku-: davet etmek, okumak(NRS,1963:244).

70. olor-: oturmak (T 18, KT D 1, 5, vd.). Nog. olttr-: oturmak; yerleşmek (NRS, 1963: 245).

71. olort-: oturtmak (KT D 26, KÇ 24, Bi I 2, vd.). Nog. olturt-: oturtmak (NRS, 1963: 245).

72. ̈çeş-: kavga etmek, çekişmek (U5:(B1.II) A2-3). Nog. öses-: inatlaşmak; kavga etmek (NRS, 2018: 507).

73. $\quad$ ögleş-62: birlikte karar vermek; anlaşmak (T 20, 20). Nog. oylas-: düşünmek, değerlendirmek (NRS, 1963: 242).

ökün-: pişman olmak (KT D 23, 40, vd. ). Nog. ökin-: pişman olmak (NRS, 1963: 257).

\footnotetext{
6o Clauson odgur- "uyandırmak" sözcü̆üünü Kıpçak Türkçesinde oyğat-/oyat- biçiminde kullanıldığını belirtir (ED: 48). Sözcükler farklı ettirgen çatı ekleriyle türetilmiştir.

ET okl- sözcüğünün asıl anlamı "yüksek sesle çağırmak”tır. Daha sonra sözcük “çağırmak, sesli olarak okumak", son olarak da günümüzdeki biçimiyle "okumak" anlamını kazanmıştır (ED: 79).

ET ögleș- sözcüğü ile NT oylas- sözcüğü semantik olarak birbiriyle örtüsmektedir. Ancak bu iki sözcüğün köklerinin ortak olması biraz şüphelidir. ET ögleş- sözcügü ög "akıl” < ö- "düşünmek" kökünden türemiştir. NT oylas- sözcüğü oy "düşünce" sözcügüünden türemiştir. V. Türk, Türk lehçelerindeki oy "düşünce" sözcügünün Arapçadan alıntı olduğunu ve rey sözcüğünün karşılığı olarak oy ver- "düsünceyi açığa vurmak" anlamında kullanıldığını belirtir (2006: 6). Ergönenç ise ET ög “düşünce, akll” sözcüğü ile NT oy “düşünce” sözcüğünü ortak olarak değerlendirmiştir (2007: 163). ET ile NT arasındaki ses denkliklerini incelediğimizde bu iki sözcüğün ortak olması muhtemeldir.
} 
78.

79.

80.

81.

82.

83.

84.

85

86.

87.

88.

89

90.

91.

92.

94

97.

93. teg-: değmek; saldırmak, (T 11, 11, KT D 32, 32, vd.). Nog. tiy-: değmek (NRS, 1963: 350).

95. t té-: demek, söylemek (T 5, 15, 30, 30, vd.). Nog. de-: demek, söylemek (NRS, 1963: 99).

96. tèr-: toplamak (KT G 10, KT D 12, BK K 8, vd.). Nog. teri-: toplamak (NRS, 1963: 347).

ölür-: öldürmek (KT K 1, T 10, 10, 21, 30, vd.). Nog. öltir-: öldürmek (NRS, 1963: 258). övkele-: öfkelenmek, kızmak (IrkB 58). Nog. öpkele-: alınmak, üzülmek (NRS, 1963: 260). saç-: saçmak, dağıtmak (IrkB 20). Nog. şaş-: saçmak, dağıttmak (NRS, 1963: 408). sanç-: mızraklamak (KT K 2, 5, 5, vd.). Nog. şanşı-: sokmak, saplamak (NRS, 1963: 404). seçlin-: seçilip ayrılmak (E 43/2; A 88/2). Nog. şeşil-: çözülmek; ayrılmak (NRS, 1963: 411). semrit-: semirtmek (IrkB 16). Nog. semirt-: semirtmek (NRS, 1963: 294). sew-: sevmek. (Kağıda Yz: IrkB 3). Nog. süy-: sevmek (NRS, 1963: 314). sewin-: sevinmek. (BK D 2, 41, IrkB 30, 31, vd.). Nog. süyin-: sevinmek (NRS, 1963: 314). sokuş-: karşlaşmak; çarpışmak. (IrkB 2, 6, 27, vd.). Nog. sok-: vurmak (NRS, 1963: 300). sökür-: diz çöktürmek (KT D 2, 15, 18, vd.). Nog. şöktir-63: çöktürmek (NRS, 1963: 416). sözle-: söylemek (Adrianov/3; U 179: A 4). Nog. söyle-: söylemek (NRS, 1963: 306). sözleş-: sözleşmek, konuşmak (BK D 21, KT D 26; A 11). Nog. söyles-: konuşmak (NRS, 1963: 307).

87. sözlet-: söyletmek (Adrianov/3; A 11). Nog. söylet-: söyletmek (NRS, 1963: 307).

şaş-: ayrlmak, çözülmek (ŞU G 9). Nog. şeş-: çözmek; ayırmak (NRS, 1963: 412).

89. şaşurt-: karıştırmak, şaşırtmak (Aç I 1). Nog. sastur-: karışıklığa neden olmak (NRS, 1963: 289).

9o. tap-: itaat etmek (Su 9; E 13/1, E 13/3, E 13/4, vd.). Nog. tab-: tapmak (NRS, 1963: 324).

1. Tartsş-: karşıllıklı yağmalamak (KarB I, IV/9). Nog. tartıs-: çekişmek (NRS, 1963: 336).

92. taş-: artmak, çoğalmak (E 28/7). Nog. tast-: taşmak (NRS, 1963: 339).

94. terit-: terletmek (IrkB 50). Nog. terlet-: terletmek (NRS, 1963: 347). tèril-: toplanmak, derlenmek (BK D 11, 29, vd.). Nog. teril-: toplanmak (NRS, 1963: 347).

ET sökür- sözcüğü -(ü)r- ettirgen çatı ekiyle, NT şöktir- sözcüğü -tir- ettirgen çatı ekiyle türetilmiştir. 
98. thth-64: parçalanmak, yolunmak (IrkB 44). Nog. tüt-: ditmek (NRS, 1963: 373).

99. tirgür-: diriltmek (KT D 29, BK D 23). Nog. tirilt-: diriltmek (NRS, 1963: 352).

100. tod-: doymak (KT G 8, BK K 6). Nog. toy-: doymak (NRS, 1963: 354).

101. toytar-: yıkmak, devirmek (Ta D 8). Nog. töyter-: devirmek, altını üste getirmek (NRS, 1963: $361)$.

102. töküt-: döktürmek (T 52). Nog. töktir-: döktürmek (NRS, 1963: 360).

103. tug-: doğmak (E 9/2, E 29/1, E 68/10; IrkB 26, vd.). Nog. tuv-: doğmak (NRS, 1963: 364).

104. tugur-: (güneş) doğmak (ŞU D 1; Ot. Ry. 8130: A 2). Nog. tuvdrr-: doğurmak (NRS, 1963: $364)$.

105. turgur-: kaldırmak (ŞU D 2; IrkB 20). Nog. turğız-: kaldırmak (NRS, 1963: 365).

106. tutul-: tutulmak, ele geçirilmek (Tes B 4). Nog. tutıl-: tutulmak (NRS, 1963: 367).

107. tutun-: tutunmak (T 25). Nog. tuttn-: tutunmak (NRS, 1963: 367).

108. tutuz-65: tutturmak (KT D 38). Nog. tutgız-: tutturmak (NRS, 1963: 367).

109. tüg-: düğümlemek (IrkB 50). Nog. tüy-: bağlamak (NRS, 1963: 369).

110. tüş-: düşmek, inmek (T 16, 30, ŞU G 2, 5, 7, vd.). Nog. tüs-: düşmek (NRS, 1963: 372).

111. tüşür-: indirmek (T 27; E 48/6). Nog. tüsir-: düşürmek, indirmek (NRS, 1963: 370).

112. tüzül-: düzeltmek, iyi duruma getirmek (KT G 5, BK K 3). Nog. tüzel-: düzelmek (NRS, 1963: 368).

113. uç-: uçmak, ölmek (KT D 16, 30, BK D 13, 14, vd.). Nog. uş-: uçmak (NRS, 1963: 385).

114. udı-66: uyumak (T 51). Nog. uyı-: koyulaşmak, tutmak (yoğurt); uyuşmak (NRS, 1963: 382).

115. unt-: unutmak (Or. 8212/78: (A) A 9-10). Nog. umet-: unutmak (NRS, 1963: 382).

116. urtur-: vurdurmak (KT G 12, 12, Ar 3, vd.). Nog. urder-: vurdurmak (NRS, 1963: 381).

117. utuz-67: kaybetmek (IrkB 29). Nog. uttrr-: kaybetmek (NRS, 1963: 384).

118. ürküt-: ürkütmek (IrkB 21). Nog. ürkit-: ürkütmek, korkutmak (NRS, 1963: 390).

\footnotetext{
64 Clauson ET tıtın- sözcügünün kökünün tıt- "parçalamak” eylemi olduğunu belirtir (ED: 458). ET tutuz- sözcüğü - $(u) z$ - ettirgen çatı ekiyle, NT tutgız- sözcüğü -gız- ettirgen çatı ekiyle türetilmiştir.

Clauson $u d$ - sözcüğünün esas olarak "uyumak" anlamını karşıladığını ancak sözcüğün "(kan, süt vb.) pıhtılaşmak, kesilmek, koyulaşmak; uyuşmak; ihmalkâr olmak, uyuşuk olmak” gibi birçok mecazî anlamı da karşıladığını belirtir (ED: 42-43).

${ }_{67} \quad$ ET utuz- sözcüğ $\ddot{u}-(u)_{Z}$ - ettirgen çatı ekiyle, NT uttır- sözcüğü -tır- ettirgen çatı ekiyle türetilmiştir.
} 
119. ütle-: ögüt vermek (O 11, 11). Nog. ögitle-: öğütlemek (NRS, 1963: 255).

120. yag-: yağmak (IrkB 53, 53). Nog. yav-: yağmak (NRS, 1963: 453).

121. yagıla-: savaşmak (45/4). Nog. yavla-: düşmanca davranmak (NRS, 1963: 453).

122. yagıt-/yagıd-: düşmanlaşmak (KÇ 5, 18, ŞU G 4). Nog. yavlas-68: düşmanlaşmak (NRS, 1963: 453).

123. yagrı-: (atın sirtı) yara olmak (IrkB 16). Nog. yavrı-: yara olmak (atın sirtında) (NRS, 1963: 454).

124. yagut-: yaklaştırmak (KT G 5, BK K 4). Nog. yovıt-: yaklaştırmak (NRS, 1963: 446).

125. yakala-: sınırı tutmak (ŞU D 8, ŞU G 2). Nog. yakla-: tutmak (NRS, 1963: 458).

126. yalga-: yalamak (IrkB 13). Nog. yala-: yalamak (NRS, 1963: 459).

127. yalk-: bıkmak(Mainz 403a,b:(B) A 3, 12). Nog. yalsk-: sıkılmak; üzülmek(NRS,1963: 461).

128. yalvar-: yalvarmak (IrkB 19, 54, Or. 8212/1692: A). Nog. yalbar-: yalvarmak (NRS, 1963: 459).

129. yamaş-: eklenmek (Ta D 6). Nog. yamas-: yamamak, lehimlemek (NRS, 1963: 463).

130. yayra-: ses çlkarmak (IrkB 22). Nog. yayıra-: ötmek; çınlamak; yankılanmak (NRS, 1963: 465).

131. yé-: yemek (T 8, T 8; IrkB 37, 46, 46, vd.). Nog. ye-: yemek (NRS, 1963: 104).

132. yèrlen-: yerleşmek, yurt tutmak (42/5). Nog. yerles-: yerleşmek (NRS, 1963: 107).

133. yėt-: yetişmek, ulaşmak (ŞU D 1, 3, ŞU G 8; vd.). Nog. yet- 4: yetişmek (NRS, 1963: 108).

134. yıg-: bir araya toplamak (T 43, O 1, O 9). Nog. yıy-: toplamak, yığmak (NRS, 1963: 127).

135. $\quad$ yıgla-: ağlamak (A 79/2). Nog. yıla-: ağlamak (NRS, 1963: 128).

136. yıril-/yiril-: ayrılmak (E 24/7, E 28/1, E 41/6). Nog. yırıl-: yırtılmak (NRS, 1963: 130).

137. yoluk-: karşılaşmak (ŞU G 1). Nog. yolık-: karşlaşmak; buluşmak (NRS, 1963: 125).

138. yorı-: yürümek (BK D 10, 27, T 29, vd.). Nog. yurı-: gitmek, yürütmek (RNS, 1956: 685).

139. yort-: yürütmek (KT G 4, BK K 3, 4, T 25, vd.). Nog. yurt-: yürütmek (NRS, 1963: 451).

140. yul-: yolmak; koparmak (IrkB 8, 8). Nog. yulk-: yolmak, koparmak (NRS, 1963: 448). 
141. yügür-: koşmak; akmak (T 52; IrkB 15, 16, vd.). Nog. yüvir-: koşmak (NRS, 1963: 445).

\section{Fonetik ve morfolojik olarak değişmeyen sözcükler}

\section{1. Ad soylu sözcükler}

1. $\quad \boldsymbol{a k}$ : ak, beyaz (KT D 35, 36, 40, KT K 5, 6, vd.). Nog. $\boldsymbol{a k}$ : beyaz (NRS, 1963: 32).

2. ala: ala, karışık renkli (IrkB 2). Nog. ala: ala; benekli (NRS, 1963: 36).

3. $\quad$ alp: alp, kahraman (KT D 3, 3, 40, vd.) Nog. alp/alpp: alp, kahraman (NRS, 2018: 67, 71).

4. $\quad$ alt: $\operatorname{altı}(K T$ D 31, 31, 34, KT K 5, BK D 1, vd.). Nog. altı: altı (NRS, 1963: 39).

5. $\quad$ ana: anne, ana (T-3/3; A 46). Nog. ana: anne (NRS, 1963: 42).

6. ara: $\operatorname{arasinda}(K T$ D 1, 2, BK D 2, 4, T 54, vd.). Nog. ara: ara, mesafe (NRS, 1963: 44).

7. arka: arka, surt (KÇ 21, HT XXI). Nog. arka: $\operatorname{arka~(NRS,~1963:~46).~}$

8. arkar69: dişi dağ keçisi (ŞU G 1). Nog. arkar: dağ keçisi; yabanî koyun (NRS, 2018: 84).

9. arslan: $\operatorname{arslan}(\mathrm{E}$ 44/6, E 44/6; Or. 8212/78: (C-D) A1). Nog. arslan: aslan (NRS, 1963: 46).

10. art: art, arka (E 41/10; IrkB 6, Or. 8212/78: (B) A 5). Nog. art: arka (NRS, 1963: 47).

11. $\boldsymbol{a s}^{70}$ : kakım (hayvan) (E 98/6, E 123). Nog. as: kakım, gelincik (hayvan) (NRS, 2018: 92).

12. at I71: ad, isim, unvan. (KT D 20, 31, KT D 25, vd.). Nog. at 1: ad, isim (NRS, 1963: 51). at II: at (binek hayvan) (KT D 32, 33, 33, 33, vd.). Nog. at 2: at (hayvan) (NRS, 1963: 52). ata: baba (E 104/8, Adrianov/2; T-2/6, T-10/5, T-3/3). Nog. ata: baba (NRS, 1963: 52). ataman: kişi unvanı (BK G 14). Nog. ataman: erkek, ataman (NRS, 1963: 52). ay: ay (dünyanın uydusu) (KT K-D, KT K-D, BK G 10, vd.). Nog. ay: ay (NRS, 1963: 27). ayak: kap kacak (IrkB 42, 42, 42). Nog. ayak 2: kase, tas (NRS, 1963: 57).

18. az: az, fazla değil (KT G 10, KT D 29, 40, BK K 7, vd.). Nog. az: az (NRS, 1963: 27). bakar: bakır; para (E 79, E 26/7). Nog. bakur: bakır (NRS, 1963: 67).

ET’de arkar sözcüğü Şine Usu yazıtında bir yer adında arkar başı "İrtiş Irmağı'nın başka bir ırmak ile birleşme yeri" olarak geçer (Aydın, 2016: 15). Kaşgarlı DLT'de arkar sözcüğüyle ilgili "boynuzundan bıçak sapı yapılan dağ keçisi" bilgisini verir (Ercilasun vd. 2015: 58). Bu hayvan Moğolca-Türkçe sözlükte argali olarak bulunur ve sözlükte "Asya dağlarında yaşayan çok büyük, boynuzlu bir çeșit yaban koyunu, dağ koyunu" olarak anlamlandırılmıştır (Lessing 2003: 83). Clauson Moğolcadaki argali sözcügünün Türkçeden ödünçleme olduğunu belirtir (ED: 216).

7o Tepsey VIII (E 123) yazıtında sözcük $a z$ biçiminde yazılmıştır. Clauson sözcügün asıl şeklinin as olduğunu, $a z$ yazımının alternatif biçim olduğunu ve sözcükte uzun ünlü ile ötümsüz sonses ünsüzünün birleşiminin siradışı olduğunu belirtir (ED: 240). Aydın, sözcükteki yazım farklılı̆̆ının yazıcının hatasıyla ortaya çıtı̆̆ını düşünür (2016: 17). 
20. bal: bal (ŞT). Nog. bal: bal (NRS, 1963: 68).

21. bar: var, mevcut (KT G 9, 11, KT D 29, 29, BK K 7, vd.). Nog. bar: var (NRS, 1963: 70).

22. bars: bars, leopar (E 10/9, E 14/1, E 17/1, E 28/4, vd.). Nog. bars: pars (RNS, 1956:35).

23. bay: zengin (KT G 10, BK D 14, 23, E 17/1, vd.). Nog. bay: zengin; koca (NRS, 1963: 66).

24. $\quad$ bek $\boldsymbol{k}^{\mathbf{7}}$ : sağlam (Ar 1). Nog. bek: sağlam; pek (NRS, 1963: 75).

25. berk: sağlam, dayanıklı (Adrianov/2, 2). Nog. berk: güçlü, sağlam (NRS, 1963: 75).

26. bir: bir (KT G 6, 8, KT D 32, 33, 36, vd.). Nog. bir: bir, tek (NRS, 1963: 81).

27. biz: birinci çokluk kişi zamiri. (KT D 20, T 8, 13, 16, vd.). Nog. biz: biz (NRS, 1963: 79).

28. boz: boz, gri. (KT D 32, 33, 37, 37, KÇ 4, vd.). Nog. boz: boz, gri (NRS, 1963: 83).

29. böri: kurt (KT D 12, BK D 11; Ç, DU I 2; E 11/10, vd.). Nog. böri: kurt (NRS, 1963: 87).

30. bulgak: karışıklık (E 15/1). Nog. bulgak: karışık (NRS, 1963: 90).

31. bulnt: bulut (IrkB 52, 52, 53, 53). Nog. bulnt: bulut (NRS, 1963: 90).

32. er: asker, adam, erkek. (KT D 12, 13, 13, 31, 39, vd.). Nog. er: erkek, er (NRS, 1963: 437). erk: güç, kudret (E 29/4, E 98/1; A 7/2, A 7/1, vd.). Nog. erk: irade (NRS, 1963: 438). erksiz: güçsüz, kudretsiz (Mainz 388: B 6). Nog. erksiz: iradesiz (NRS, 1963: 438). esen: sağ, sağlıklı (Han 4, ZO 2; E 24/10, E 38/5; YÇ II, vd.). Nog. esen: sağlıklı (NRS,44O).

36. et: et (IrkB 23). Nog. et: et, kas (NRS, 1963: 442).

37. in: in, yabani hayvan yuvası (IrkB 8). Nog. in: in, vahşi hayvan ini (NRS, 1963: 119).

38. ingen: dişi deve. (E 28/3; IrkB 5). Nog. ingen: dişi deve (NRS, 2018: 230).

39. ini: küçük erkek kardeş (KT D 26, 27, 30, vd.). Nog. ini: küçük kardeş (NRS, 1963: 119).

40. kagan: kağan (KT G 1, 3, 9, 9, KT D 1, vd.). Nog. kagan: kağan (NRS, 1963: 396).

41. kalın: kalın, yoğun (BK D 25, T 13; E 28/2, vd.). Nog. kalın: kalın (NRS, 1963: 142).

42. kalıy: başlık (parası, değeri) (Su 7). Nog. kalıy: başlık (parası, malı) (NRS, 1963: 142).

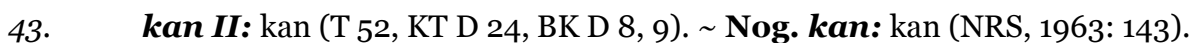

\footnotetext{
72 Clauson ET bek "sağlam, sıkı, istikrarlı" sözcüğü ile berk "sağlam, dayanıklı" sözcüğ̈̈nün aynı olduğunu ve berk sözcügüünü asıl; bek sözcüğünün ise ikincil biçim olduğunu belirtir (ED: 323). NT'de her ikisi de bulunmaktadır. 
44. $\quad$ kanat: kanat (IrkB 3, 35). Nog. kanat: kanat (NRS, 1963: 144).

45. $\quad$ kar: $\operatorname{kar}(K T$ D 35, BK D 27, T 25). Nog. kar: kar (NRS, 1963: 147).

46. kara: siyah; avam (KT D 8, 38, 39, BK D 8, vd.). Nog. kara: siyah; halk (NRS, 1963: 147).

47. karm: karın (IrkB 6). Nog. karm: karın; mide (NRS, 1963: 152).

48. kat: kat, tabaka (U 177: B 3, IrkB 9, 50). Nog. kat: kat, katman (NRS, 1963: 154).

49. katr/katng: katı, sert (ŞU D 6, HT V/2, ON 2; IrkB 65, 65). Nog. katı: sert (NRS, 1963: 155).

50. kaya: kaya (Ar 1, 2, 3; E 39/1, E 39/5, vd.). Nog. kaya: kaya (NRS, 1963: 156).

51. $\quad$ kek: kötü niyet, kin, öç (Mainz 386: B 1). Nog. kek: intikam; kin (NRS, 1963: 158).

52. kelin/keliy: gelin (KT K 9; E 3/6). Nog. kelin: gelin (NRS, 1963: 159).

53. $\quad$ kurk: $\operatorname{kirk}($ KT D 15, KT K 2, KT K-D; E 23/1, vd.). Nog. kurk: kırk (NRS, 1963: 201).

54. Keyın: ceza (T 32; ŞU D 2). Nog. kıyın: zor; utandıran, zor duruma düşüren (NRS, 1963: 199).

55. kzz: kız (KT D 7, 24, BK D 7, 20, T 48, vd.). Nog. kzz: kız (NRS, 1963: 196).

56. $\quad$ kzzıl: kızıl, kırmızı (T 52; IrkB 51). Nog. kzzıl: kızll, kırmızı (NRS, 1963: 197).

57. kim: $\operatorname{kim}($ KT D 9, 22, BK D 8, 19, Mainz 169a,b+c,d). Nog. kim: kim (NRS, 1963: 166).

58. $\quad k$ kol: kol, el (T-2/4). Nog. kol: el (NRS, 1963: 167).

59. k kök: mavi, gri; gök (KT D 1, 3, BK D 2, vd.). Nog. kök: gök; mavi; yeşil (NRS, 1963: 177).

6o. köl: göl (KT D 34, 34, KT K 2, 2, Tes K 3, vd.). Nog. köl: köl (NRS, 1963: 178).

61. $\quad$ könek73: kova. (Kağıda Yz: IrkB 57, 57). Nog. könek: deri (NRS, 1963: 179).

62. körrk: güzel, güzellik (HT XV/5; Mainz386: A 2-3). Nog. $\boldsymbol{k o ̈ r r k : ~ g u ̈ z e l l i k ; ~ d o g ̆ r u l u k ~ ( N R S , ~ 1 9 6 3 : ~}$ 180).

63. k köz: göz (KT K 10, 11, 11, BK D 2, KT Kap. 5, vd.). Nog. köz: göz (NRS, 1963: 176).

64. kul: köle, kul (KT D 7, 20, 21, 24, BK D 7, vd.). Nog. kul: kul, köle (NRS, 1963: 186).

65. kulan: yaban eşeği (DU I 2). Nog. kulan: kulan (yabanî hayvan) (NRS, 1963: 186).

66. kurt: kurt, solucan (T II T 14: A 28-29). Nog. kurt: kurt, solucan (NRS, 1963: 189).

73 Clauson könek "kova" sözcüğünün kön "küçük deri eşya" sözcügünden türediğini belirtir (ED: 731). IrkB 57'de könek sözcüğü iki kez geçer ve birinde sözcük / $\eta /$ harfi ile diğerinde $/ n$ / harfi ile yazılmıştır. Türk lehçelerinde sözcük könek biçiminde bulunduğu için sözcüğün köyek yazımı yanlış olabilir. 
67. kut: baht, saadet (BK D 25, 35, KT D 29, 31, vd.). Nog. $k u t:$ mutluluk (NRS, 1963: 190).

68. kün: gün; güneş (KT G 2, 2, 2, KT D 4, vd.). Nog. kün: gün; güneş; hava (NRS, 1963: 193).

69. küp: küp (Or. 8212/77: A 10). Nog. küp: küp (NRS, 2018: 398).

70. küz: güz (HT II/3, ŞU D 8). Nog. küz: güz, sonbahar (NRS, 1963: 191).

71. ne: ne (KT D 9, BK D 9, 28, T 14, 32, vd.). Nog. ne: ne (NRS, 1963: 235).

72. ok: ok; boy (KT D 33, 36; E 43/4, E 5/1, vd.). Nog. ok: ok, mermi (NRS, 1963: 243).

73. on: on (KT G 12, KT D 19, KT K 7, T 26, 36, vd.). Nog. on: on (NRS, 1963: 246).

74. ot 174: ateş (KT D 27, BK D 22; Or.8212/76: (B) B 9, vd.). Nog. ot 1: ateş (NRS, 1963: 252).

75. $\quad$ ot 2: ot, bitki (IrkB 17, 53, 45, Or.8212/76: (B) B 9). Nog. ot 2: ot; bitki (NRS, 1963: 253).

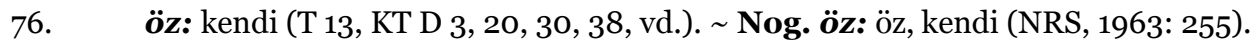

77.

78. $\quad$ sansız: sayısız (BK G 12; Su 5). Nog. sansız: sayısız (NRS, 1963: 287).

79. semiz: besili (T 5, 6; IrkB 65). Nog. semiz: semiz (NRS, 1963: 294).

80. sen/sin: $\operatorname{sen}(T$ 10, ŞU D 5, DU II 3; Mainz 403A,B: (B) B4). Nog. sen: sen (NRS,1963: 294).

81. $\quad$ sın75: mezar, kabir (KÇor 12). Nog. sm: figür; kişi, insan vücudu; heykel (NRS, 1963: 320).

82. sımar: yarı, yarım (BK D 32, 32, T 40, vd.). Nog. sımar: çiftin teki, tek (NRS, 1963: 321).

83. siz: siz (ŞU D 10, İHN; E 26/13; Mainz 388: A 7). Nog. siz: siz (NRS, 1963: 296).

84. söz: söz (ŞU B 5; IrkB 7, 11). Nog. söz: söz; kelime (NRS, 1963: 305).

85. $\quad$ tal76: ağaç (E 41/1). Nog. tal: söğ̈̈; dal (NRS, 1963: 328).

86. tam: duvar (KT G-D). Nog. tam: duvar, sur (NRS, 1963: 330).

87. tay: tan, şafak (vakti) (T 35; IrkB 26). Nog. tay: tan, şafak (NRS, 1963: 333).

$74 \quad$ Clauson sözcüğün uzun ünlülü olduğunu belirtir (ED: 34).

75 ET sin sözcüğü ile NT sin sözcüğünün ortak olması süphelidir. DLT’de (Ercilasun vd. 2015: 819) ve Clauson’un sözlüğünde (ED: 832) "mezar" ve "insan vücudu, boyu” anlamlarında olmak üzere iki farklı sin sözcüğ̈̈ vardır. Eski Anadolu Türkçesi ve Anadolu ağızlarında bulunan sin "mezar; ölüm; kahır" sözcüğü de ET sin "mezar" sözcügüüle ilişkilendirilmiştir. Sözcüğün sin biçimi, şayet başka dilden alıntı değilse, art ünlülü sin sözcüğünün ünlüsünün incelmesiyle ortaya çıkmıştır (Aydın, 2013: 164). sın sözcügü çağdaş Kumuk Türkçesi sözlüğünde (Pekacar, 2011: 293) ve Karaçay-Balkar Türkçesi sözlüğünde (Tavkul, 2000: 342) "mezar" anlamıyla, diğer Çağdaş Kıpçak Türk lehçeleri sözlüklerinde (Yudahin, 2011: 650; Baskakov, 1958: 603; Öner, 2015: 406; Özşahin, 2017: 198) "insan vücudu, boyu" anlamıyla tanıklanmıştır. Farklı anlamlarda olan sın sözcükleri "mezarın insanın vücuduna, boyuna göre yapılması" gibi bir düşünceyle iki sözcüğün ilişkili olması ihtimalini düsündürmektedir.

76 En eski anlamı "dal” olan tal sözcüğü sonraları "söğ̈̈̈t ağacı" anlamını da karşlar olmuştur (ED: 489). Sözcük "soy, nesil” anlamını da karşlar (Ayazlı, 2016: 218). 
88. tay/tañ: tay (KÇ 15; E 41/5, E 41/11, E 41/2, vd.). Nog. tay: tay (NRS, 1963: 326).

89. temir: demir (KT G 4, KT D 2, 8, 17, vd.). Nog. temir: demir (NRS, 1963: 344).

90. tey: denk, eşit, emsal (A 6/2, A 6/2) 77. Nog. tey: aynı, denk, eşit (NRS, 1963: 345).

91. ter: ter (T 52). Nog. ter: ter (NRS, 1963: 346).

92. teri: deri (IrkB 44). Nog. teri: teri (NRS, 1963: 347).

93. tezek: tezek, kuş pisliği (IrkB 23). Nog. tezek: tezek (NRS, 1963: 343).

94. tilek: dilek (E 135/3). Nog. tilek: dilek (NRS, 1963: 351).

95. tiz: $\operatorname{diz}(\operatorname{IrkB} 60) . \sim$ Nog. tiz: $\operatorname{diz}(\mathrm{NRS}, 1963:$ 349).

96. tok: tok (T 8; Tes K 5). Nog. tok: tok (NRS, 1963: 354).

97. toz: toz (IrkB 15). Nog. toz/tozan: toz (NRS, 1963: 354).

98. tul: dul (E 45/6; T-13/2, T-1/2, T-3/4). Nog. tul: dul (RNS, 1956:67).

99. tuman: duman (IrkB 15). Nog. tuman: sis, duman (NRS, 1963: 365).

100. tuzak: tuzak (IrkB 61). Nog. tuzak: tuzak, kapan (NRS, 1963: 364).

101. tün: gece (BK K 2, 11, BK D 22, T 12, 22, vd.). Nog. tün: gece (NRS, 1963: 370).

102. tüz: birlik içinde (olan); düz (KT D 3, BK D 4; U 178: A 4). Nog. tüz: düz (NRS,1963: 368).

103. uya: yuva, in. (E 28/6; E 15/1; T-13/5; IrkB 31). Nog. uya: yuva, in (NRS, 1963: 386).

104. uzak: uzak (T 52). Nog. uzak: uzak (NRS, 1963: 379).

105. ün: ses (AÖ-2; U 171a,b: (A) A 3 (?)). Nog. ün: ses (NRS, 1963: 390).

106. yaka: yaka, uç, sınır (ŞU D 8, ŞU G 2, ŞU B 2). Nog. yaka: yaka (NRS, 1963: 454).

107. yalay: yalın, çıplak (KT D 28, 29, BK D 22,vd). Nog. yalay: çıplak; yalın(NRS, 1963: 459).

108. yan/yen: yan, cephe (T 11, 33, 26, ŞU G 1, vd.). Nog. yan: yan, taraf (NRS, 1963: 463).

109. yamı: yeni (Ar 1, ŞU K 9, ŞU D 1, 3, 5, vd.). Nog. yamı: yeni (NRS, 1963: 465).

110. yası: yassı (Ta B 3, ŞU D 9). Nog. yası: geniş, yassı (NRS, 2018: 831).

Oçurı (E-26) yazıtının 8. satırında da bir tẹ sözcüğü bulunmaktadır. Türkologlar bu sözcüğe metnin anlam bütünlügüne uygun olduğu için genellikle "sayı, miktar" anlamını vermiştir (Aydın, 2019: 101-102). Tekin (2003: 254)

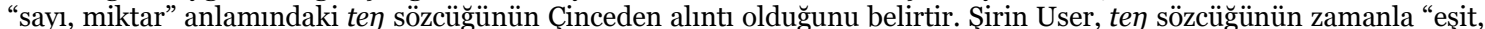
denk; karşılık" anlamından "bir malın karşılık değeri, alım veya satımda denk gelen parasal karşllı̆̆ı" anlamına geliștiğini düşünür ve sözcügüun "sayı" anlamına geçişini semantik olarak olanaklı görür (2009: 169). 
111. yat: yabanc1, el (E 11/7; T II T 14: A 23). Nog. yat: yabancı (NRS, 1963: 472).

112. yazı: ova, düzlük yer (KT G 3, 7, BK K 5, T 33, 36, vd.). Nog. yazı: bozkır; kır (NRS, 1963: 456).

113. yıl: yll (KT D 8, BK D 7, BK G 9, 9, 10, vd.). Nog. yıl: yll, sene (NRS, 1963: 128).

114. yılan: yılan (Ta D 5, Ta B 1, HT XIV/2; IrkB 8, vd.). Nog. yılan: yılan (NRS, 1963: 128).

115. $\quad$ yılkz $^{78}$ : at; at sürüsü (BK D 24, 38, 39, KT G-B, vd.). Nog. yzlkz: at (NRS, 1963: 128).

116. yıllk: yıllık (Ta B 2, ŞU D 9). Nog. yıllkk: yıllık (NRS, 1963: 128).

117. yok: yok, mevcut değil (KT G 3, 3, 4, 8, 10, vd.). Nog. yok: yok (NRS, 1963: 124).

118. yol: yol; şans, talih (T 16, 23, 23, 24, KT K 9, vd.). Nog. yol 1: yol (NRS, 1963: 124).

119. yolsız: yolu olmayan (T 35). Nog. yolsız: yolsuz (NRS, 1963: 125).

120. yurt: yurt (KT K 9, T 19; E 101, E 72/2; IrkB 13). Nog. yurt: yurt; ev (NRS, 1963: 451).

121. yük: yük (E 28/3). Nog. yük: yük (NRS, 1963: 447).

122. yürek: yürek. (E 44/1, E 69/1; A 78). Nog. yürek: yürek, kalp, gönül (NRS, 1963: 450).

123. yüz I: surat (KT D 33, HT XV/4; E 26/9, vd.). Nog. yüz 1: yüz (NRS, 1963: 446).

124. yüz II: yüz (sayı) (KT D 13, 13, 33, T 4, 4, vd.). Nog. yüz 2: yüz (sayl) (NRS, 1963: 446).

\section{2. Eylemler}

1. $\quad \boldsymbol{a l}$-: almak, ele geçirmek (BK K 9, 10,10, BK D 8, T 32). Nog. $\boldsymbol{a l}$-: almak (NRS, 1963: 37).

2. alda-: aldatmak, hile yapmak (Or.8212/78: (C-D) A5). Nog. alda-: aldatmak(NRS,1963: 37).

3. $\quad$ alın-: alınmak (E 11/2). Nog. alın-: alınmak, kabul edilmek (NRS, 1963: 40).

4. arzl-: mahvolmak; yorulmak(KT G 9, BK K 7). Nog. arll-: yorulmak, bitmek(NRS,1963: 48).

5. $\quad$ art-: $\operatorname{artmak}(\mathrm{E} \mathrm{42/4,} \mathrm{E} \mathrm{28/7,} \mathrm{E} \mathrm{48/4,} \mathrm{E} \mathrm{48/5,} \mathrm{vd.).} \mathrm{Nog.} \mathrm{art-:} \mathrm{artmak} \mathrm{(NRS,} \mathrm{1963:} \mathrm{47).}$

6. aşa-: yemek yemek (U 5: (B1.I) A 7-8). Nog. aşa-: yemek yemek (NRS, 1963: 54).

7. at-: atmak, firlatmak (E 28/5, E 41/7). Nog. at-: atmak (NRS, 1963: 53).

8. ata-79: atamak; adlandırmak (Ta G 5, 6, 6, 6, vd.). Nog. ata-: adlandırmak(NRS, 1963: 52).

\footnotetext{
78 Temel olarak "çiftlik hayvanları, dört ayaklı" anlamlarını karşılayan yılkı sözcüğü daha sonra "sı̆̆ır, at" gibi hayvanlar için de kullanılmştır. Budist terminolojide "koyun, deve" gibi hayvanlar için de kullanılmıştır (ED: 925-926). ata- sözcüğünün asıl anlamı "bir kişiyi adıyla çă̆ırmak, kişiye seslenmek”tir; daha sonra sözcük anlam genişlemesiyle "bir işe atamak; nişanlamak (gelecekteki eşi olarak adlandırmak), adamak" anlamını; bu son anlamdan da söz vermek" anlamını kazanmıştır (ED: 42).
} 
9. $\quad$ atlan-: ata binmek (KÇ 20). Nog. atlan-: ata binmek (NRS, 1963: 53).

10. ayt-8o/ayıt-/ayıd-: söylemek (T 24, 44, 47, vd.). Nog. ayt-: söylemek (NRS, 1963: 30).

11. az-: yolunu kaybetmek, sapmak (IrkB 15, 15, vd.). Nog. az-: azmak (NRS, 1963: 28).

12. bar-: varmak, gitmek (KT D 34, 39, BK D 20, 32, vd.). Nog. bar-: varmak (NRS, 1963: 70).

13. bas-: basmak (BK D 27, 32, T 27, 38, KT D 35, vd.). Nog. bas-: basmak (NRS, 1963: 73).

14. bat-: batmak (güneş) (ŞU D 1). Nog. bat-: batmak (NRS, 1963: 74).

15. bil-: bilmek, anlamak (KT G 11, 12, 13, BK K 8, vd.). Nog. bil-: bilmek (NRS, 1963: 81).

16. bol-: olmak (KT D 4, 5, 5, 9, 12, vd.). Nog. bol-: olmak; yardımcı eylem (NRS, 1963: 84).

17. bulga-: karıştırmak (KÇ 11, ŞU G 4). Nog. bulga-: karıştırmak (NRS, 1963: 90).

18. bulgat-: karıştırtmak (Ta D 5). Nog. bulgat-: sallamak, karıştırmak (NRS, 1963: 93).

19. buz-: bozmak, dağıtmak (BK D 24, 25, 34, 34, vd.). Nog. buz-: bozmak (NRS, 1963: 89).

20. ez-: ezmek (Aç I 2). Nog. ez-: ezmek, buruşturmak, basmak (NRS, 1963: 431).

21. ilin-: takılmak, yakalanmak(IrkB 61). Nog. ilin-: çengele asılmak, takılmak(NRS,1963: 119).

22. kal-: kalmak (BK K 7, KT K 9, T 4, T 13, 19, vd.). Nog. kal-: kalmak (NRS, 1963: 142).

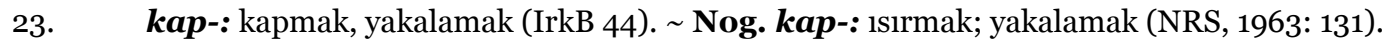

24. $\quad k e l-:$ gelmek (KT D 28, 31, 37, KT K 12, 12, vd.). Nog. kel-: gelmek (NRS, 1963: 159).

25. kes-: kesmek (IrkB 8). Nog. kes-: kesmek (NRS, 1963: 163).

26. kez-: boyunca yürümek; gezmek (Aç I 1; A 6/1). Nog. kez-: gezmek (NRS, 1963: 158).

27. kal-: yapmak, etmek. (BK D 3, 7, 7, 13, 14, vd.). Nog. kal-: yapmak (NRS, 1963: 199).

28. kzlın-: yaratılmak (T 1, 18, KT D 1, BK D 2, vd.). Nog. kzlın-: yapılmak (NRS, 1963: 200).

29. kzz-: kızmak, sinirlenmek. (T 40). Nog. kzz-: sinirlenmek; sicaklı̆̆ı artmak (NRS, 1963: 197).

30. kir-: girmek (KT D 38, BK K 14, BK D 38, vd.). Nog. kir-: girmek (NRS, 1963: 167).

31. kon-: yerleşmek, konmak (KT G 5, 7, BK K 4, vd.). Nog. kon-: konmak (NRS, 1963: 172).

32. $\quad$ kork-: $\operatorname{korkmak}(\mathrm{T}$ 39; IrkB 2, 19, 2). Nog. $\boldsymbol{k o r k}$-: korkmak (NRS, 1963: 173).

8o ayıt- eylemi ay- eyleminin ettirgen çatı eki alarak türemiş şeklidir. Ünlü harfle başlayan eklerden önce çoğunlukla aytşeklinde yazılır. Asıl olarak "söyletmek" ki bu da "sormak" anlamını ifade eder. XI. yüzyl gibi ettirgen anlamını kaybetmiş ve sonradan kullanılmayan ay- eylemi ile aynı anlamda olmuştur (ED: 268). 
33. kön-81: düz olmak (fiziksel) (Or. 8212/76: A). Nog. kön-: kabul etmek, anlaşmak (ED: 726).

34. $\quad$ kör-: görmek; itaat etmek (KT D 19, 30, BK D 2, vd.). Nog. kör-: görmek (NRS, 1963: 181).

35. $\quad$ közle-: gözlemek, gözetlemek (IrkB 64). Nog. közle-: gözlemek; izlemek (NRS, 1963: 177).

36. küt-: beklemek (ŞU D 5). Nog. küt-: beklemek (NRS, 2018: 402).

37. ok/ök: kuvvetlendirme edatı(T 42, 50,vd.). Nog. ok 2: kuvvetlendirme edatı(NRS,1963: 243).

38. oy-: (beniz) solmak (IrkB 17). Nog. oy- 2: solmak; dökülmek (NRS, 1963: 248).

39. oy-: oymak (IrkB 29). Nog. oy-: oymak (NRS, 1963: 254).

40. oz-: kurtulmak; geçmek (KT K 7, IrkB 13, 17, 41, vd.). Nog. oz-: geçmek (NRS, 1963: 240).

41. ̈̈l-: ölmek (BK K 6, KT D 19, 19, 20, 33, vd.). Nog. öl-: ölmek (NRS, 1963: 259).

42. ̈r-: isyan etmek; kalkmak (KT B; İA-A2 3). Nog. ör-: kalkmak (NRS, 1963: 261).

43. ̈̈rten-: yanmak (IrkB 9). Nog. örten-: yanmak; acı çekmek (NRS, 1963: 262).

44. öt-: geçmek (U 177: A 3). Nog. öt-: geçmek (NRS, 1963: 264).

45. $\quad$ sık-: sıkıştırmak, bastırmak (ŞU D 4). Nog. sık-: sıkmak (NRS, 1963: 320).

46. $\quad$ sin-82: kirılmak (IrkB 6). Nog. sin-: kırılmak (NRS, 1963: 321).

47. sök-: sökmek (T 25, BK G 8, BK D 27, KT D 35). Nog. sök-: sökmek (NRS, 1963: 305).

48. sür-: sürmek (KT D 23, BK D 19, KÇ 20, ŞU G 2). Nog. sür-: sürmek (NRS, 1963: 316).

49. tamgala-: damgalamak (Mainz 388: A 4-5). Nog. tamgala-: damgalamak (NRS, 1963: 331).

50. tuyla-: dinlemek (KT G 2, BK K 1; IrkB 58). Nog. tıyla-: dinlemek (NRS, 1963: 375).

51. tik-: dikmek (KT G 11, KT D 16, 24, BK D 13, vd.). Nog. tik-: dikmek (NRS, 1963: 350).

52. tile-: dilemek, istemek (T 23; IrkB 24). Nog. tile-: dilemek, istemek (NRS, 1963: 351).

53. tiril-: dirilmek (IrkB 13). Nog. tiril-: dirilmek (NRS, 1963: 352).

54. tokz-: vurmak, dövmek (KT K 6, ŞU G 2, 5, vd.). Nog. tokz-: dokumak (NRS, 1963: 356).

55. toknt-: vurdurmak, yazdırmak (KT G 12, 13, vd.). Nog. toknt-: dokutmak (NRS, 1963: 356).

\footnotetext{
${ }_{81} \quad$ Clauson kön- "düz olmak (fiziksel)" sözcügünün Türk dillerinde "kabul etmek, anlaşmak” gibi farklı anlamlarda yașamını sürdürdüğünü belirtir (ED: 726).

ET sın- "kırılmak” sözcüğünün kökü olan sl- "kırmak” sözcüğü KT D, T 19 ve KÇ 21'de tanıklanmıştır. NT sözlüklerinde st- kök sözcüğü bulunmaz. Bunun yerine "kırmak" anlamı sözcügün türemiş biçimi olan sındır- sözcügüyle karşlanır. 
56. tolgat-83: eziyet, acı çekmek (BK K 13). Nog. tolgat-: doğum sancıları çekmek (NRS, 1963: 356).

57. toy-: donmak (IrkB 57, 57). Nog. toy-: donmak (NRS, 1963: 357).

58. tökk-: dökmek (KÇ 17, Tes K 3, Ta D 2). Nog. tök-: dökmek (NRS, 1963: 360).

59. tur-I: yardımcı eylem; durmak (IrkB 15, vd.). Nog. tur-1: yardımcı eylem (NRS, 1963: 366).

6o. tur-II: ayağa kalkmak, yükselmek (KÇ 21). Nog. tur-2: ayağa kalkmak (NRS, 1963: 366).

61. tut-: tutmak (BK K 6, BK D 3, KT D 1, 32, 38, vd.). Nog. tut-: tutmak (NRS, 1963: 367).

62. tuy-: duymak, sezmek (ŞU K 10; IrkB 61). Nog. tuy-: hissetmek, sezmek (NRS, 1963: 367).

63. una-: onaylamak (E 109/4; IrkB 38, U 5: (B1. II) B 5-6). Nog. una-: beğenmek (NRS, 1963: $383)$.

64. ur-: vurmak; taşa yazmak (T 34, BK K 8, 8, 8, vd.). Nog. ur-: vurmak (NRS, 1963: 383).

65. ut-: yenmek, kazanmak (T II T 14: A 18, IrkB 29). Nog. ut- : kazanmak (NRS, 1963: 384).

66. ürk-: ürkmek, korkmak (ŞU G 7; IrkB 27). Nog. ürk-: ürkmek, korkmak (NRS, 1963: 391).

67. $\quad$ üz-: kopmak (T 13). Nog. ӥz-: koparmak (NRS, 1963: 387).

68. yayıl-: yanılmak (KT G 6, 10, BK K 4, 8, 8, vd.). Nog. yayıl-: yanılmak (NRS, 1963: 465).

69. yayıla-: yenilemek; tekrar etmek (KarB I, III/9). Nog. yayıla-: yenilemek (NRS, 1963: 465).

70. yay-/yañ: yaymak, dağıtmak (O 1, T 16, vb.). Nog. yay-: sermek, yaymak (NRS, 1963: 474).

71. yar-: yarmak, ikiye bölmek (IrkB 40). Nog. yar-: yarmak (NRS, 1963: 469).

72.

yara-: yaramak (T 23; ŞU D 10; IrkB 5, 5, 41, vd.). Nog. yara-: yaramak (NRS, 1963: 466).

73 .

yarat-: yaratmak (BK K 9, 9, BK D 2, 16, 17, vd.). Nog. yarat-: yaratmak (NRS, 1963: 467).

74 .

yartl-: yarılmak (IrkB 6). Nog. yarl-: yarılmak (NRS, 1963: 469).

75 .

yarlıka-: lütfetmek (BK D 13, 14, 23, 33, vd.). Nog. yarlıka-: bağışlamak (NRS, 1963: 469).

76.

yaşa-: yaşamak (KÇ 3, KT K 2, 2; E 36/1). Nog. yaşa-: yaşamak (NRS, 1963: 474).

77.

yat-: yatmak (KT D 24, BK D 20, KT K 9, T 19, vd.). Nog. yat-: yatmak (NRS, 1963: 472).

78.

yayla-: yazı geçirmek. (Ta B 2, IrkB 62, vd.). Nog. yayla-: yazı geçirmek (NRS, 1963: 457).

83 Clauson ET tolga- sözcüğünün temelde "bükmek, sarmak" anlamlarını karşıladığını, sözcüğün bazı Türk dillerinde "midenin kötüleşmesi, vb.” gibi farklı anlamları da karşıladığını belirtir (ED: 497). Clauson tolgat- sözcüğüne de "acı ve ıdıraba neden olmak" anlamını vermiştir (ED: 497). 
79. yel-: (at) hızlı sürmek (T 26, 27). Nog. yel-: tırıs gitmek; koşmak (NRS, 1963: 106).

80. yet-: (bir atı) yedeğe almak; götürmek (T 25). Nog. yet-7: sürmek, yönetmek, götürmek (NRS, 1963: 108).

81. yılla-: yılı geçirmek (Ta G 2). Nog. yılla-: yıl boyunca durmak (NRS, 1963: 128).

\section{Sonuç}

1. Eski Türk runik metinlerinde özel isimleri (kişi, yer, millet, boy, dağ, ırmak, göl vs.), birleşik sayıları ve aynı eylemlerin hem olumlu hem de olumsuz şekilleri varsa olumsuz şekillerini karşılaştırma için kullanmadığımızda karşımıza 1264 sözcük çıkmıştır. Bu 1264 sözcüğü Nogay Türkçesi sözlüklerinde aradığımızda ortak olan toplam 670 (\% 53) sözcük tespit edilmiştir. Ortak sözcüklerin 448’i $(\% 66,8)$ ad soylu sözcük, 222'si (\% 33,2) ise eylemdir. Ortak olan sözcüklerden 205’i herhangi bir fonetik veya morfolojik değişikliğe uğramadan Nogay Türkçesinde kullanılmaya devam etmektedir. Runik metinlerde bazı sözcüklerin sadece kök biçimi bulunup türemiş biçimleri bulunmamakta veya kök biçimi bulunmayıp türemiş biçimleri bulunmaktadır. Bu durum dikkate alındığında, çağdaş Nogay Türkçesinde yaşamaya devam eden Eski Türkçe sözcüklerin tespit edilenden daha fazla olduğu şüphesizdir.

2. Ortak olan sözcüklerin bir kısmı Nogay Türkçesinde bazı ses değişikliklerine uğramıştır. Bu ses değişikliklerini aşağıdaki tablo yardımıyla gösterebiliriz. ${ }^{84}$ Buradaki ses değişikliklerini incelediğimiz eserlerde sözcüklerin yazılmış biçimlerine göre tespit ettiğimizi belirtmek isteriz.

\begin{tabular}{|c|c|c|c|c|c|c|c|}
\hline \multicolumn{4}{|c|}{ Ünlüler } & \multicolumn{4}{|c|}{ Ünsüzler } \\
\hline ET & NT & Örnek Sözcük & Adet & ET & NT & Örnek Sözcük & Adet \\
\hline$a$ & $u$ & yavaş>yuvas & 1 & $b$ & $m$ & buy $>$ muy & 11 \\
\hline$a$ & $e$ & amti>endi & 4 & $b$ & $p$ & bıç->piş- & 3 \\
\hline$a$ & $o$ & ança>onşa & 6 & $c ̧$ & $S ̧$ & $a c ̧>a s ̧$ & 50 \\
\hline$a$ & $l$ & taş>tıs & 1 & $d$ & $y$ & adak>ayak & 22 \\
\hline$e$ & $i$ & beg $>$ biy & 8 & $d$ & $t$ & $\ddot{o} d>\ddot{o} t$ & 3 \\
\hline$e$ & $a$ & $e \eta>a \eta$ & 3 & $g$ & $v$ & agul $>$ avil & 35 \\
\hline$e$ & $\ddot{u}$ & $e w>\ddot{u} y$ & 6 & $g$ & $y$ & beg $>$ biy & 13 \\
\hline$e$ & $u$ & tegül>tuvıl & 1 & $g$ & $k$ & $k \imath s g a>k \imath s k a$ & 17 \\
\hline$\dot{e}$ & $e$ & $b \dot{e} l>b e l$ & 25 & $k$ & $g$ & ékiz>egiz & 14 \\
\hline$\dot{e}$ & $i$ & kèyik>kiyik & 3 & $k$ & $k$ & kan $>$ kan & 3 \\
\hline$\dot{e}$ & $a$ & yèl>yal & 1 & $m$ & $n$ & amtr>endi & 1 \\
\hline$\imath$ & $i$ & it $>$ iyt & 5 & $m$ & $p$ & altmış>alpıs & 2 \\
\hline$\imath$ & $u$ & yımşak>yumsak & 5 & $m$ & $b$ & azman>azban & 1 \\
\hline$\imath$ & $a$ & ıgaç>agaş & 3 & $n$ & $\eta$ & yinçge>yinişke & 1 \\
\hline$\imath$ & $e$ & trak>erek & 1 & $n$ & $y$ & kanta $>$ kayda & 3 \\
\hline 2 & $\ddot{u}$ & tıt->tüt- & 1 & $n$ & $m$ & unt->umit- & 1 \\
\hline
\end{tabular}

84 Tabloda bulunan “adet” başlı̆̆ının altındaki sayılar, ilgili ses değişikliğinin kaç sözcükte tanıklandığını belirtmektedir.

Address Turkish Language and Literature, Kayalı Campus-Kırklareli/TURKEY e-mail: editor@rumelide.com 


\begin{tabular}{|c|c|c|c|c|c|c|c|}
\hline$i$ & $l$ & yégirmi>yırma & 3 & $\tilde{n}$ & $n$ & azkıña $>$ azgana & 2 \\
\hline$i$ & $e$ & idi>iye & 6 & $\tilde{n}$ & $y$ & $k o \tilde{n}>k o y$ & 3 \\
\hline$i$ & $a$ & yégirmi>yırma & 2 & $\eta$ & $g$ & baya $>$ maga & 4 \\
\hline$o$ & $u$ & $b o>b u$ & 9 & $\eta$ & $n$ & terin>teren & 5 \\
\hline$o$ & $a$ & boto $>$ bota & 3 & $\eta$ & $y$ & sünük>süyek & 1 \\
\hline$o$ & $\ddot{o}$ & toytar->töyter- & 1 & $p$ & $b$ & köpük>köbik & 4 \\
\hline$\ddot{o}$ & $e$ & töpö>töbe & 2 & $S$ & $s$ & adaş>adas & 49 \\
\hline$\ddot{O}$ & $\ddot{u}$ & közed->küzet- & 2 & $t$ & $d$ & anta $>$ anda & 14 \\
\hline$u$ & $l$ & $a c ̧ u k>a s ̧ ı k$ & 46 & $v$ & $p$ & övkele->öpkele- & 1 \\
\hline$u$ & $a$ & boguz>bogaz & 8 & $v$ & $b$ & yalvar->yalbar- & 1 \\
\hline$u$ & $i$ & bişur->pisir- & 1 & $w / b$ & $y$ & ewir->üyir- & 6 \\
\hline$\ddot{u}$ & $i$ & belgü>belgi & 39 & $w / b$ & $v$ & $a w>v$ & 8 \\
\hline$\ddot{u}$ & $l$ & tegül>tuvul & 1 & $z$ & $y$ & sözle->söyle- & 3 \\
\hline$\ddot{u}$ & $e$ & kötür>köter- & 3 & & & & \\
\hline$\ddot{u}$ & $\ddot{o}$ & ütle->ögitle- & 1 & & & & \\
\hline
\end{tabular}

Tablo 1: Eski Türkçeden Nogay Türkçesine sözcüklerde gerçekleşen ses değişiklikleri.

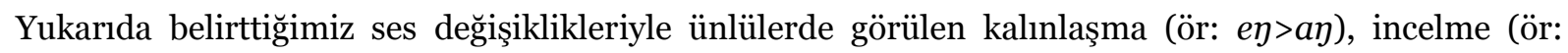
trak>erek), düzleşme (ör: belgü>belgi), yuvarlaklaşma (ör: ança>onşa), daralma (ör: beg >biy), genişleme (ör: boguz>bogaz); ünsüzlerde görülen tonlulaşma (ör: köpük>köbik), tonsuzlaşma (ör: kısga>kıska), akıcılaşma (ör: adak>ayak), sızıcılaşma (ör: $a c ̧>a s ̧$ ), süreksizleşme (ör: altmış>alpıs) gibi ses olaylarının yanında, Nogay Türkçesindeki sözcüklerde aşağıdaki ses olayları da görülmüsştür:

Yaygın olarak NT sözcüklerde iç seste ünlü türemesi olduğu görülmüştür: ilk>ilik, kişne>kisine-, korkunç>korkınış, ökünç>ökiniş, ters >teris.

ET bazı sözcüklerde iç seste bulunan /1/ ünlüsünün NT'de sözcük türetilirken düştüğü görülmüştür: tawışgan >tavşan, yakılıg >yaklı.

ET tilkü sözcüğündeki iki ünlünün NT’de >tülki biçiminde yer değiştirdiği görülmüştür.

NT’de bazı sözcüklerin ortasında iki ünlü arasında ünsüz ikizleşmesi görülmüştür: elig>elli, isig>issi, ulug $>$ ull.

emgek>embek sözcüğünde /m/ ünsüzü kendinden sonraki ünsüzü kendisi gibi dudak ünsüzü yaparak ilerleyici ünsüz benzeşmesi gerçekleşmiştir.

NT'de birçok sözcükte önceki ünsüz sonraki ünsüze benzeyerek gerileyici ünsüz benzeşmesi gerçekleşmiştir: öçes->öses-, saç>şaş, saç->şaş-, sıçgan >şışkan.

bè>biye, ıt>iyt sözcüklerinde iç seste /y/ ünsüzü, öt>ögit sözcüğünde iç seste /g/ ünsüzü, yarın> yavırın sözcüğünde de iç seste /v/ ünsüzü türemiştir.

ET sözcüklerin ortasındaki ve sonundaki art damak /g/ sesi, NT'de bazı sözcüklerde /v/ sesine dönüşmüş (ör: adıg>ayıv, agıl>avıl, agır >avır, arıg>aruv, ayag >ayav, azıg $>$ azuv, bag $>$ bav, bagır $>$ bavır 
tug->tuv-, yadag>yayav); bazı sözcüklerde ise düşmüştür (ör: açıg>aşı, elig>elli, kırıg>kır, ogrı>urı, oglan $>$ ulan, ogul $>$ ul, ölüg $>$ öli, sarıg $>$ sarı, torug $>$ torı). Bu ses değişimi veya düşmesinin herhangi bir kalınlık-incelik veya düzlük-yuvarlaklık durumuna göre bir sisteme bağlandığı çalışmamızda tespit edilememiştir. Ayrıca buzagu>buzav, kugu>kuv, küdegü>kiyev sözcüklerinde -gU ses grubu /v/ sesine dönüşmüştür.

ET +lIg addan ad türeten yapım ekinin sonundaki $/ g /$ sesi NT’de düşmüştür. Ayrıca altmış>alpıs sözcüğünde / $t$ / sesi, kulkak>kulak sözcüğünde / $k$ / sesi, nençe>neşe sözcüğünde /n/ sesi, yuyka>yuka sözcügünde /y/ sesi, kuwra->kura- sözcügünde /w/ sesi düşmüştür.

NT'de ünlülerde genel olarak kalınlık-incelik uyumu vardır, düzlük-yuvarlaklık uyumu yoktur. Ünsüzlerde ise genel olarak ünsüz uyumu vardır.

3. Türk runik metinlerdeki bazı sözcükler Nogay Türkçesinde anlam daralması, anlam genişlemesi ve anlam değişmesine uğrayarak kullanılmaktadır.

Anlam daralması olan sözcüklere şu örnekler verilebilir: tonlug "giyimli" > tonl "kürklü", tal "ağaç" > tal "söğüt ağacı; dal", yılkı "at sürüsü; çiftlik hayvanları" > yılkı "at", oglan "çocuklar" > ulan "erkek çocuk", ayak "kap kacak" > ayak 2 "kase, tas", tolgat- "eziyet, acı çekmek" > tolgat- "doğum sancıları çekmek".

Anlam genişlemesi olan sözcüklere şu örnekler verilebilir: agıl "ağıl, hayvanların barındığı yer" > avıl "köy", katun "kağanın karısı" > ḳatın "kadın", sanç- "mızraklamak" > şanşı- "sokmak, saplamak", yakala- "sınırı tutmak" > yakla- "tutmak", bay "zengin" > bay "zengin; erkek eş, koca”.

Anlam değişmesi olan sözcüklere şu örnekler verilebilir: arıg "temiz, saf" > aruv "iyi, güzel", awlak "av yeri" > avlak "tenha; uzak, kuytu", başlıg "lider; lideri olan" > bash "başlı; akıllı", buyruk "komutan" > buyrı "emir, ferman", emgek "sıkıntı, ızdırap" > embek "yük, külfet”, koş "(muvakkaten kullanılan) çadır" > kos "geçici yurt", monçuk "kıymetli taş" > moyşak "boncuk; kolye", tuş "eşit, eş değer" > tus "yön; karşı taraf", utuş "uğur, yol" > utıs "kazanç, ikramiye", yolagçı "öncü birlik" > yolavşı "yolcu", öçeş- "kavga etmek, çekişmek" > öses- "inatlaşmak", kıyın "ceza" > kıyın "zor; utandıran, zor duruma düşüren”, könek "kova” > könek "deri”, kön- "düz olmak" > kön- "kabul etmek, anlaşmak".

\section{Kisaltmalar}

$\begin{array}{llll}\text { Aç } & \text { Açit Yazıtları } & \text { KB } & \text { Kuru-Bakayır Yazıtı } \\ \text { akt. } & \text { aktaran } & \text { KÇ } & \text { Küli Çor Yazıtı } \\ \text { AÖ } & \text { Ak-Ölön Yazıtı } & \text { KÇor } & \text { Karı Çor Tegin (Xi'an) Yazıtı } \\ \text { Ar } & \text { Arhanan Yazıtı } & \text { K-D } & \text { Kuzey-Doğu (Yüzü) } \\ \text { B } & \text { Batı (Yüzü) } & \text { KMTS } & \text { Karaçay Malkar Türkçesi Sözlüğü } \\ \text { Bi } & \text { Biger Yazıtları } & \text { KRS } & \text { Karakalpaksko-Russkiy Slovar } \\ \text { BK } & \text { Bilge Kağan Yazıtı } & \text { KS } & \text { Krrgız Sözlüğü } \\ \text { bk. } & \text { Bakınız } & \text { KT } & \text { Köl Tegin Yazıtı } \\ \text { BO } & \text { Baga Oygor Yazıtı } & \text { KTS } & \text { Kazak Türkçesi Sözlüğü } \\ \text { Bö } & \text { Bömbögör Yazıtı } & \text { KTTS } & \text { Kazan-Tatar Türkçesi Sözlüğ̈̈ } \\ \text { BTS } & \text { Başkurt Türkçesi Sözlüğ̈̈u } & \text { Kum } & \text { Kumtura Yazıtları } \\ \text { c. } & \text { cilt } & \text { KuTS } & \text { Kumuk Türkçesi Sözlüğü } \\ \text { Ç } & \text { Çoyr Yazıtı } & \text { MT } & \text { Mutrın Temdeg Yazıtı }\end{array}$




$\begin{array}{llll}\text { ÇKTL } & \text { Çă̆daş Kıpçak Türk Lehçeleri } & \text { Nog. } & \text { Nogayca } \\ \text { D } & \text { Doğu (Yüzü) } & \text { NRS } & \text { Nogaysko-Russkiy Slovar } \\ \text { Da } & \text { Darvi Yazıtı } & \text { NT } & \text { Nogay Türkçesi } \\ \text { DEGK } & \text { Devlet Ermitajı'ndan Gümüş Kap } & \text { O } & \text { Ongi Yazıtı } \\ \text { DLT } & \text { Divan-ı Lûgâti’t-Türk } & \text { ON } & \text { Olon Nuur Yazıtı } \\ \text { DU } & \text { Del Uul Yazıtları } & \text { OTG } & \text { Orhon Türkçesi Grameri } \\ \text { ED } & \text { An Etymological Dictionary Of Pre- } & \text { Ö } & \text { Örük Yazıtları } \\ & \text { Thirteenth-Century Turkish } & \text { RNS } & \text { Russko-Nogayskiy Slovar } \\ \text { ET } & \text { Eski Türkçe } & \text { S. } & \text { sayfa } \\ \text { G } & \text { Güney (Yüzü) } & \text { Su } & \text { Suci Yazıtı } \\ \text { G-B } & \text { Güney-Batı (Yüzü) } & \text { ŞT } & \text { Şaahar Tolgoy Yazıtı } \\ \text { G-D } & \text { Güney-Doğu (Yüzü) } & \text { ŞU } & \text { Şine Usu Yazıtı } \\ \text { Han } & \text { Hangiday Yazitı } & \text { T } & \text { Tonyukuk Yazıtı } \\ \text { HT } & \text { Hoyto-Tamır Yazıtları } & \text { T-1 } & \text { Talas-1 Yazıtı vd. } \\ \text { IrkB } & \text { Irk Bitig } & \text { Ta } & \text { Tariat (Terh) Yazıtı } \\ \text { Iş } & \text { Işar Yazıtı } & \text { TDK } & \text { Türk Dil Kurumu } \\ \text { İA } & \text { İhe Ashete Yazıtı } & \text { Te } & \text { Tevş Yazıtı } \\ \text { İHN } & \text { İhi Hanın Nor Yazıtı } & \text { vb. } & \text { ve benzeri } \\ \text { İl } & \text { İllük Yazıtı } & \text { vd. } & \text { ve diğerleri } \\ \text { İnç } & \text { İnçkü Yazıtı } & \text { Y } & \text { Yorçı Yazıtı } \\ \text { K } & \text { Kuzey (Yüzü) } & \text { YÇ } & \text { Yilig Çor Yazıtları } \\ \text { K-1 } & \text { Koçkor-1 Yazıtı vd. } & \text { YT } & \text { Yemiş Tutuk Yazıtı } \\ \text { Kap. } & \text { Kaplumbağa Altlıtaki Yazıt } & \text { YU } & \text { Yamanı Us Yazıtı } \\ \text { KarB } & \text { Karabalgasun Yazıtı } & \text { ZO } & \text { Züriyn Ovoo Yazıtı } \\ & & & \end{array}$

\section{Kaynakça}

Alimov, R. (2014). Tanrı Dağı Yazıtları. Konya: Kömen Yayınları.

Alkaya, E. (2002). Kuzey Grubu Türk Lehçelerinde Edatlar. Doktora Tezi. Elazı̆̆: Frrat Üniversitesi.

Alyılmaz, C. (2004). Kutlugun Mührü (Mutrın Temdeg Yazıtı). A. Ü. Türkiyat Araştırmaları Enstitüsü Dergisi, 23, 1-6.

Alyılmaz, C. (2013). Yorçı Yazıtı. TEKE Dergisi, 2/3, 29-46.

Alyılmaz, C. (2015). İpek Yolu Kavşağının Ölümsüzlük Eserleri. Ankara: Atatürk Üni. Yayınları.

Ayazlı, Ö. (2016). Eski Uygurca Din Dışı Metinlerin Karşılaştırmalı Söz Varlı̆̆ı, Ankara: Türk Dil Kurumu Yayınları.

Aydın, E. (2013). Olon Nuur / Galuut (Moğolistan) Yazıtı Üzerine Notlar. Bengü Beläk. Ahmet Bican Ercilasun Armă̆anı. Ed. Bülent Gül. Ankara: TKAE Yayınları. 123-130.

Aydın, E. (2013). Tariat ve Xi’an (Karı Çor Tegin) Yazıtları Işığında Sın 'Mezar' Sözcüğü Üzerine. Belleten, 61/2, 161-166.

Aydın, E. (2015). Yenisey Yazıtları. Konya: Kömen Yayınları.

Aydın, E. (2016). Eski Türk Yazıtlarında Bitkiler ve Hayvanlar. Türk Kültürü, IX/1, 1-51.

Aydın, E. (2017a). Orhon Yazıtları (Köl Tegin, Bilge Kağan, Tonyukuk, Ongi, Küli Çor). İstanbul: Bilge Kültür Sanat Yayınları.

Aydın, E. (2017b). Türk Runik Bibliyografyası. İstanbul: Bilge Kültür Sanat Yayınları.

Aydın, E. (2018a). Taşa Kazınan Tarih Türklerin İlk Yazılı Belgeleri. İstanbul: Kronik Yayınları.

Aydın, E. (2018b). Uygur Yazıtları. İstanbul: Bilge Kültür Sanat Yayınları.

Aydın, E. (2019). Sibirya'da Türk İzleri. İstanbul: Kronik Yayınları. 
Barutçu Özönder, F. S. (2000). Eski Türk Çağı Kaya Yazıtları: I. Açit Yazıtları I-II, II. Yamanı-Us Kaya Yazitı. Kök Araştırmalar, II/2, 147-153.

Barutçu Özönder, F. S. (2006). Çöyr Yazıtı. Modern Türklük araştırmaları Dergisi, 3/3, 108-124.

Barutçu Özönder, S. (2000). Eski Türk Çağı Kaya Yazıtları: I. Örük Yazıtı, II. Hangiday Yazıtı, III. Arhanan Yazıtı. Kök Araştırmalar, II/1, 121-133.

Baskakov N.A. (1956). Russko-Nogayskiy Slovar. Moskva.

Baskakov N.A. (1958). Karakalpaksko-Russkiy Slovar. Moskva.

Baskakov N.A. (1963). Nogaysko-Russkiy Slovar. Moskva.

Battulga, T. (2005). Mongolın Runi Biçgiyn Baga Dursgaluud. Ulaanbaatar: Corpus Scriptorum.

Battulga, T. (2019). Oruk Yazıtı. Asya Araştırmaları Dergisi, 1/3, 87-100.

Bazılhan, N. (2003). Mongoliyanın Bayan-Ölgiy Aymagındagı Köne Türik Bitikderdin Janaşa Okılıuv. Otan Tarihı, 2/3, 96-100.

Buran A. \& Alkaya E. (2014). Çağdaş Türk Yazı Dilleri-III. Ankara: Akçă̆ Yayınları.

Canibekova-Qalmıqova S. A. \& Bulgarova M. A. \& Quqayeva S. A. (2018). Nogaysko-Russkiy Slovar. Nauka Vostoçnaya Literatura.

Clauson, S. G. (1972). An Etymological Dictionary of Pre-Thirteenth-Century Turkish. Oxford: Oxford Üniversity.

Ercilasun, A. B. \& Akkoyunlu, Z. (2015). Kâşgarh Mahmud Dîvânu Lugâti’t-Türk (Giriş-Metin-ÇeviriNotlar-Dizin). Ankara: Türk Dil Kurumu Yayınları.

Ercilasun, A. B. vd. (2007). Türk Lehçeleri Grameri, Ankara: Akçă̆ Yayınları.

Erdal, M. (1991). Old Turkic Word Formation: A Functional Approach to the Lexicon, I-II. Wiesbaden: Otto Harrassowitz.

Erdal, M. (2004). A Grammar of Old Turkic. Lieden-Boston: Brill.

Eren, H. (1999). Türk Dilinin Etimolojik Sözlüğ̈̈. Ankara: Bizim Büro Basımevi.

Ergönenç Akbaba, D. (2007). Nogay Türkçesi ve Türkiye Türkçesi Arasındaki Yalancı Eş Değerler. Bilig, 42, 151-176.

Ergönenç Akbaba, D. (2009). Nogay Türkçesi Grameri. Ankara: Grafiker Yayınları.

Gabain, A. v. (1988). Eski Türkçenin Grameri (çev.: Mehmet Akalın). Ankara: Türk Dil Kurumu Yayınları.

Gülensoy, T. (2007). Türkiye Türkçesindeki Türkçe Sözcüklerin Köken Bilgisi Sözlüğü, Ankara: Türk Dil Kurumu Yayınları.

https://bitig.kz/ (erişim tarihi: 30/05/2020).

Kormuşin İ. \& Mozioğlu E. \& Alimov R. \&Yıldırım F. (2016). Yenisey-Altay-Kırgızistan Yazıtları ve Kağıda Yazılı Runik Metinler. Ankara: Bilgesu Yayınclık.

Lessing, F. D. (2003). Moğolca-Türkçe Sözlük. (çev. Günay Karaağaç). Ankara: Türk Dil Kurumu Yayınları.

Li, Y-S. (2019). Türk Dillerinde Akrabalık Adları. Ankara: Türk Dil Kurumu Yayınları.

Munkhtulga, R. (2012). Baga Kharrkhan'daki Eski Türk Yazıtları. TEKE Dergisi, 1/1, 26-35.

Müller, F. W. K. (1911). Uigurica II. Abhandlungen der Königlich Preussischen Akademie der Wissenschaften, Berlin.

Orkun, H. N. (2011). Eski Türk Yazıtları. Ankara: Türk Dil Kurumu Yayınları.

Öner, M. (2013). Bugünkü Kıpçak Türkçesi. Ankara: Türk Dil Kurumu Yayınları. 
Öner, M. (2015). Kazan-Tatar Türkçesi Sözlüğü. Ankara: Türk Dil Kurumu Yayınları.

Özşahin, M. (2017). Başkurt Türkçesi Sözlüğü. Ankara: Türk Dil Kurumu Yayınları.

Pekacar, Ç. (2011). Kumuk Türkçesi Sözlüğü. Ankara: Türk Dil Kurumu Yayınları.

Şirin User, H. (2009). Hakasya Bulgusu Eski Bir Türk Mezar Taşı: Açurı (Oçurı, Ye 26) Yazıtı. Türkbilig, 17, 158-174.

Şirin, H. (2016). Eski Türk Yazıtları Söz Varlı̆̆ İncelemesi. Ankara: Türk Dil Kurumu Yayınları.

Tavkul, U. (2000). Karaçay-Malkar Türkçesi Sözlüğü. Ankara: Türk Dil Kurumu Yayınları.

Tekin, T. (1995). Türk Dillerinde Birincil Uzun Ünlüler. Ankara: Simurg Yayınları.

Tekin, T. (1999). Hemçik-Çırgakı Yazıtı. Türk Dilleri Araştırmaları, 9, 5-15.

Tekin, T. (2000). İkinci Bay-Bulun (= E 49) Yazıtı. Türk Dilleri Araştırmaları, 10, 81-90.

Tekin, T. (2003). Orhon Türkçesi Grameri. (2. Baskı), İstanbul: Sanat Kitabevi.

Tekin, T. (2019). Irk Bitig. Ankara: Türk Dil Kurumu Yayınları.

Temir, A. (2016). Moğollarm Gizli Tarihi. Ankara: Türk Tarih Kurumu Yayınları.

Tezcan, S. (1978). Eski Türkçe buyla ve baga Sanları Üzerine. TDAY-Belleten, 53-69.

Tibıkova L. N. \& Nevskaya İ. A. \& Erdal M. (2012). Katalog Drevnetyurkskih Runiçeskih Pamyatnikov. Gorno-Altaysk: Gorno-Altaysk Gosudarstvennıy U.

Tietze, A. (2002). Tarihi ve Etimolojik Türkiye Türkçesi Lugatı. İstanbul: Simurg Yayınları.

Toparlı R. \& Vural H. \& Karaatlı R. (2007). Kıpçak Türkçesi Sözlüğü. (2. Baskı), Ankara: Türk Dil Kurumu Yayınları.

Türk V. (2006). Türkçede Ö-, Ög, Ögür, Ögren-, Ögret- Kelimeleri. H. Ü. Türkiyat Araşttrmaları Dergisi, 5-15.

Uçar, E. (2012). Eski Türkçe +ll Eki Üzerine. Karadeniz Araştırmaları, 34, 135-145.

Ünal, O. (2015). İhe Ashete Yazıtı: Yeni Bir Okuma ve Anlamlandırma Denemesi. Bilig, 73, 271-294.

Yıldırım, F. (2017). Irk Bitig ve Orhon Yazıl Metinlerin Dili. Ankara: Türk Dil Kurumu Yayınları.

Yıldırım, A. (2019). Yenisey Yazıtlarında Duygu Sözcükleri. Dede Korkut Uluslararası Türk Dili ve Edebiyatı Araştırmaları Dergisi, 8/19, 272-283.

Yudahin, K. K. (2011). Kırgız Sözlüğü. (çev. Abdullah Taymas). Ankara: Türk Dil Kurumu Yayınları. 